\title{
Modelling glacier change in the Everest region, Nepal Himalaya
}

\author{
J. M. Shea ${ }^{1}$, W. W. Immerzeel ${ }^{1,2}$, P. Wagnon ${ }^{1,3}$, C. Vincent ${ }^{4}$, and S. Bajracharya ${ }^{1}$ \\ ${ }^{1}$ International Centre for Integrated Mountain Development, Kathmandu, Nepal \\ ${ }^{2}$ Department of Physical Geography, Utrecht University, Utrecht, the Netherlands \\ ${ }^{3}$ IRD/UJF - Grenoble 1/CNRS/G-INP, LTHE UMR 5564, LGGE UMR 5183, Grenoble, 38402, France \\ ${ }^{4}$ UJF - Grenoble 1/CNRS, Laboratoire de Glaciologie et Géophysique de l'Environnement (LGGE) UMR 5183, \\ Grenoble, 38041, France
}

Correspondence to: J. M. Shea (joseph.shea@icimod.org)

Received: 1 September 2014 - Published in The Cryosphere Discuss.: 17 October 2014

Revised: 7 April 2015 - Accepted: 8 April 2015 - Published: 27 May 2015

\begin{abstract}
In this study, we apply a glacier mass balance and ice redistribution model to examine the sensitivity of glaciers in the Everest region of Nepal to climate change. Highresolution temperature and precipitation fields derived from gridded station data, and bias-corrected with independent station observations, are used to drive the historical model from 1961 to 2007. The model is calibrated against geodetically derived estimates of net glacier mass change from 1992 to 2008, termini position of four large glaciers at the end of the calibration period, average velocities observed on selected debris-covered glaciers, and total glacierized area. We integrate field-based observations of glacier mass balance and ice thickness with remotely sensed observations of decadal glacier change to validate the model. Between 1961 and 2007, the mean modelled volume change over the Dudh Koshi basin is $-6.4 \pm 1.5 \mathrm{~km}^{3}$, a decrease of $15.6 \%$ from the original estimated ice volume in 1961. Modelled glacier area change between 1961 and 2007 is $-101.0 \pm 11.4 \mathrm{~km}^{2}$, a decrease of approximately $20 \%$ from the initial extent. The modelled glacier sensitivity to future climate change is high. Application of temperature and precipitation anomalies from warm/dry and wet/cold end-members of the CMIP5 RCP4.5 and RCP8.5 ensemble results in sustained mass loss from glaciers in the Everest region through the 21 st century.
\end{abstract}

\section{Introduction}

High-elevation snow and ice cover play pivotal roles in Himalayan hydrologic systems (e.g. Viviroli et al., 2007; Immerzeel et al., 2010; Racoviteanu et al., 2013). In the monsoon-affected portions of the Himalayas, meltwater from seasonal snowpacks and glaciers provides an important source of streamflow during pre- and post-monsoon seasons, while rainfall-induced runoff during the monsoon dominates the overall hydrologic cycle (Immerzeel et al., 2013). Against this backdrop, changes in glacier area and volume are expected to have large impacts on the availability of water during the dry seasons (Immerzeel et al., 2010), which will impact agriculture, hydropower generation, and local water resources availability. In the current study, our main objectives are to calibrate and test a model of glacier mass balance and redistribution, and to present scenarios of catchment-scale future glacier evolution in the Everest region.

\subsection{Study area and climate}

The ICIMOD (2011) inventory indicates that the Dudh Koshi basin in central Nepal contains a total glacierized area of approximately $410 \mathrm{~km}^{2}$ (Fig. 1). The region contains some of the world's highest mountain peaks, including Sagarmatha (Mount Everest), Cho Oyu, Makalu, Lhotse, and Nuptse. The Dudh Koshi River is a major contributor to the Koshi River, which contains nearly one-quarter of Nepal's exploitable hydroelectric potential. Approximately $110 \mathrm{~km}^{2}$, or $25 \%$ of the total glacierized area, is classified as debris-covered (Fig. 2), with surface melt rates that are typically lower than those observed on clean glaciers due to the insulating effect of the debris (Reid and Brock, 2010; Lejeune et al., 2013).

The climate of the region is characterized by pronounced seasonality of both temperature and precipitation. At $5000 \mathrm{~m}$ (see analysis below), mean daily temperatures range between -7 and $+10^{\circ} \mathrm{C}$, with minimum and maximum daily temper- 


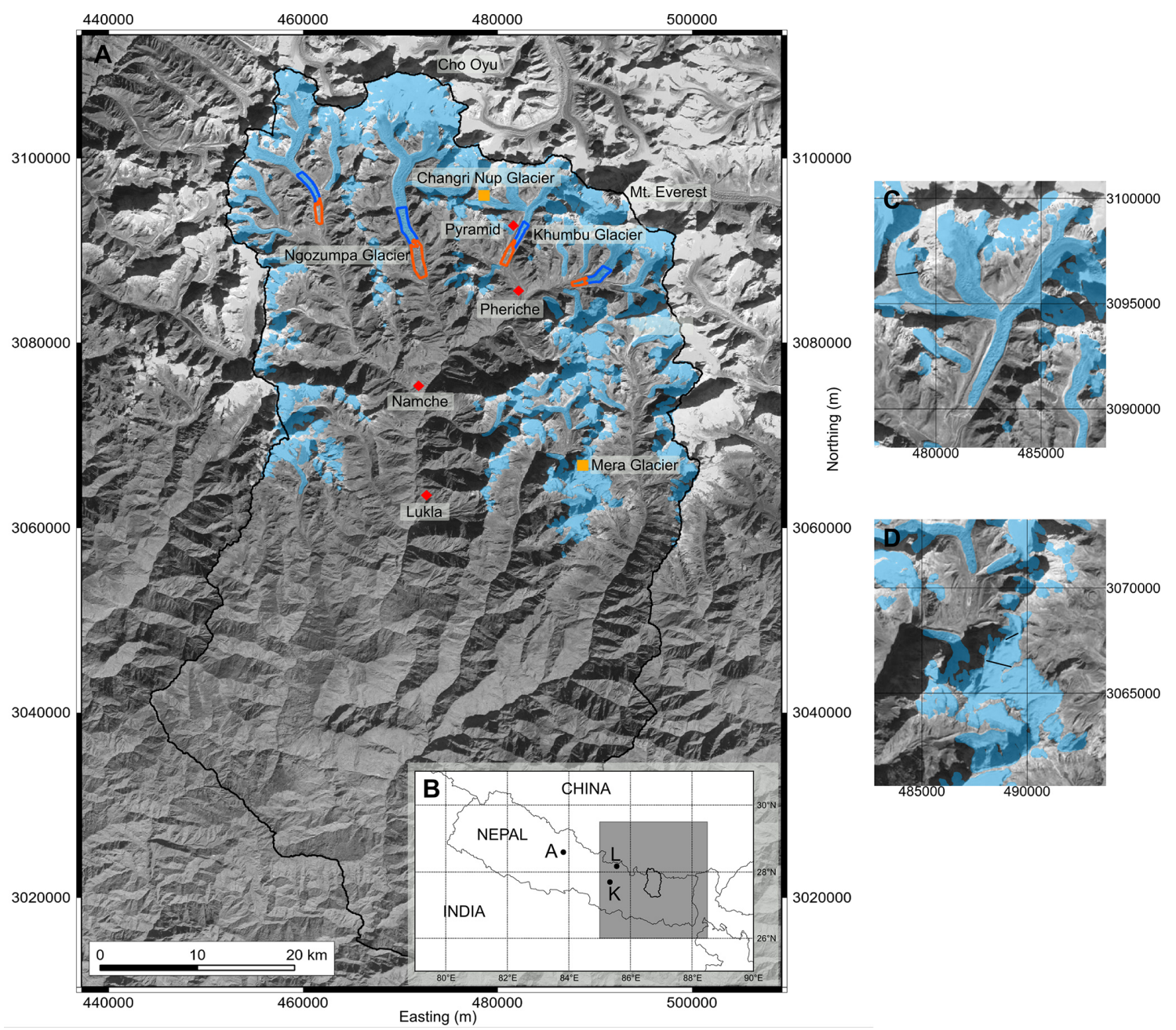

Figure 1. (a) Dudh Koshi basin, eastern Nepal, with current glacier extents in blue (ICIMOD, 2011), EVK2CNR stations (red), GPR profile sites (yellow). Extents of glacierized (blue) and non-glacierized (orange) regions used for model calibration are also shown. Coordinate system is UTM 45N. Inset map (b) shows the Dudh Koshi basin in relation to the APHRODITE subset (shaded), and the locations of places named in the text (A - Annapurna, L - Langtang, K - Kathmandu). Panels (c) and (d) give the location of the transverse GPR surveys (thick red lines) at Changri Nup and Mera glaciers, respectively.

atures ranging between -25 and $+10^{\circ} \mathrm{C}$. During the monsoon period (June-September), temperatures at $5000 \mathrm{~m}$ are greater than $0{ }^{\circ} \mathrm{C}$ and variability is low. The majority of annual precipitation (approximately $77 \%$, derived from gridded climate fields, see below) falls between 1 June and 30 September during the summer monsoon (Wagnon et al., 2013). An additional $14 \%$ of precipitation occurs during the pre-monsoon period (March-May), with little or no precipitation during the post-monsoon and winter seasons. The interaction between moisture advected from the Indian Ocean during the monsoon and the two-step topography of the Dudh Koshi region (foothills, main ranges) results in two spatial maxima of precipitation (Bookhagen and Burbank, 2006).

\subsection{Himalayan glaciology}

The current status of glaciers varies across the Hindu Kush Himalayan (HKH) region. Most areas have seen pronounced glacier retreat and downwasting in recent years (Bolch et al., 2012; Kääb et al., 2012; Yao et al., 2012), though some areas, such as the Karakoram and Pamir ranges, have experienced equilibrium or even slight mass gain (Gardelle et al., 2012, 2013; Jacob et al., 2012). In the Everest region (Fig. 1), Gardelle et al. (2013) find an average annual rate of mass loss of $-0.26 \pm 0.13 \mathrm{~m}$ w.e. $\mathrm{yr}^{-1}$ between 2000 and 2011, while Nuimura et al. (2012) estimate mass loss rates of $-0.40 \pm 0.25 \mathrm{~m}$ w.e. $\mathrm{yr}^{-1}$ between 1992 and 2008. Between 2003 and 2009, thinning rates of $-0.40 \mathrm{~m} \mathrm{yr}^{-1}$ were estimated from ICEsat data (Gardner et al., 2013), which is similar to the 1962-2002 average thinning rate of $-0.33 \mathrm{~m} \mathrm{yr}^{-1}$ 


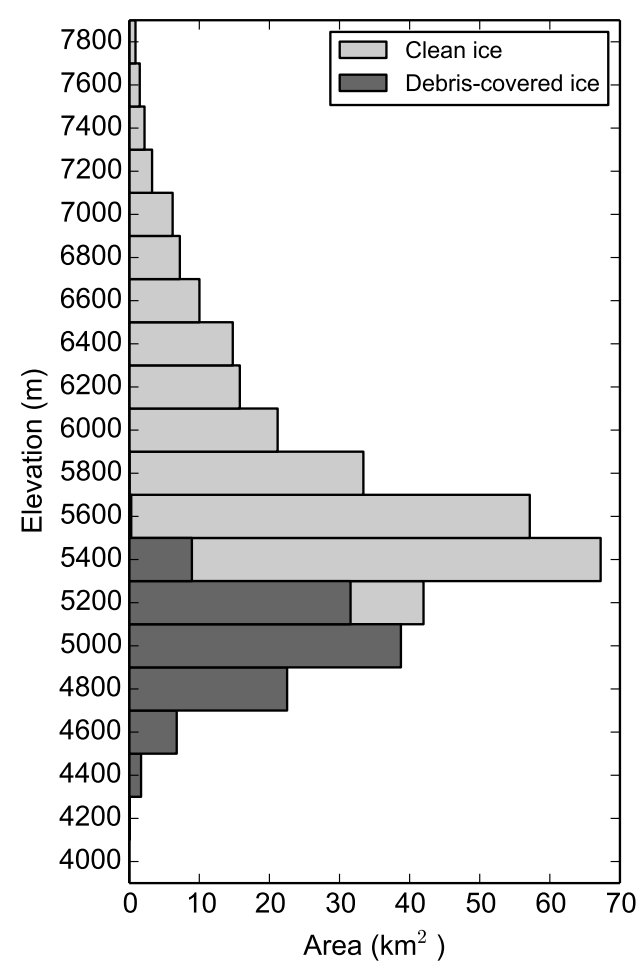

Figure 2. Area of clean and debris-covered glaciers by elevation, Dudh Koshi basin, Nepal. Extracted from SRTM 90 m DEM and glacier inventory from ICIMOD (2011)

calculated for glaciers in the Khumbu region (Bolch et al., 2008a, b). Areal extents of glaciers in Sagarmatha National Park decreased $5 \%$ during the second half of the 20th century (Bolch et al., 2008b; Salerno et al., 2008; Thakuri et al., 2014). These estimates do not distinguish between debriscovered and clean-ice glaciers.

One consequence of glacier retreat in the Himalayas is the formation of proglacial lakes, which may pose a risk to downstream communities. Terminus retreat at Lumding and Imja glaciers, measured at -42 and $-34 \mathrm{~m} \mathrm{yr}^{-1}$, respectively, between 1976 and 2000 increased to $-74 \mathrm{~m} \mathrm{yr}^{-1}$ at both glaciers between 2000 and 2007 (Bajracharya and Mool, 2010). Rapid terminus retreat results in the growth of proglacial lakes which are dammed by lateral and terminal moraines (Bolch et al., 2008b; Benn et al., 2012; Thompson et al., 2012). The failure of moraine dams in the Koshi River basin has led to 15 recorded glacier lake outburst flood (GLOF) events since 1965, with flows up to 100 times greater than average annual flow (Chen et al., 2013), and the frequency of GLOFs in the Himalayas is believed to have increased since the 1940s (Richardson and Reynolds, 2000). Changes in glacier extents and volumes in response to climate change thus have important impacts not only on water resources availability but also on geophysical hazards.

The climate sensitivity of a glacier depends primarily on its mass balance amplitude. Glaciers in wetter climates typi-
Table 1. EVK2CNR meteorological stations used to validate downscaled APHRODITE temperature and precipitation fields.

\begin{tabular}{lccc}
\hline Site & Latitude $\left(^{\circ}\right)$ & Longitude $\left(^{\circ}\right)$ & Elevation $(\mathrm{m})$ \\
\hline Lukla & 27.69556 & 86.72306 & 2660 \\
Namche & 27.80239 & 86.71456 & 3570 \\
Pheriche & 27.89536 & 86.81875 & 4260 \\
Pyramid & 27.95903 & 86.81322 & 5035 \\
\hline
\end{tabular}

cally extend to lower elevations, and are thus more sensitive to temperature changes than those in dry climates (Oerlemans and Fortuin, 1992). Himalayan glaciers, and glaciers of the Dudh Koshi in particular, present a unique challenge as observations of temperature and precipitation at high elevations are scarce. Regionally, the climate varies from monsoon-dominated southern slopes to relatively dry leeward high-elevation regions. Accordingly, equilibrium line altitudes (ELAs) in the region vary both spatially and temporally but generally range from $5200 \mathrm{~m}$ in the south to $5800 \mathrm{~m}$ in northern portions of the basin (Williams, 1983; Asahi, 2010; Wagnon et al., 2013). Nearly $80 \%$ of the glacierized area in the Dudh Koshi basin lies between 5000 and $6000 \mathrm{~m}$ (Fig. 2), and the region is expected to be sensitive to climatic changes.

\subsection{Historical and projected climate trends}

Analyses of climate trends in the region are limited, primarily due to the lack of long-term records (Shrestha and Aryal, 2011). Available studies indicate that the mean annual temperatures have increased in the region, and particularly at high elevations (Shrestha et al., 1999; Rangwala et al., 2009; Ohmura, 2012; Rangwala and Miller, 2012). Reported mean annual temperature trends range between 0.025 and $0.06^{\circ} \mathrm{C} \mathrm{yr}^{-1}$ for the periods 1971 to 2009 and 1977 to 1994, respectively (Shrestha and Aryal, 2011; Qi et al., 2013). Changes in temperature are particularly important for monsoon-type glaciers, which are sensitive to the elevation of the rain/snow threshold during the monsoon season (Bolch et al., 2012). Results from the CMIP5 (Climate Modelling Intercomparison Project) ensemble suggest that temperatures in the region will increase between 1.3 and $2.4{ }^{\circ} \mathrm{C}$ over the period 1961-1990 to 2021-2050 (Lutz et al., 2013), which correspond to rates of 0.021 to $0.040^{\circ} \mathrm{C} \mathrm{yr}^{-1}$.

Precipitation amounts, timing, and phase will affect glacier responses on both annual and decadal timescales. In the greater Himalayas, trends in precipitation totals appear to be mixed and relatively weak (Mirza et al., 1998; Gautam et al., 2010; Dimri and Dash, 2012; Qi et al., 2013), though the observational network is composed mostly of low-elevation valley stations that may not reflect changes in snowfall amounts at higher elevations. General circulation model projections suggest both increased monsoon precipitation (Kripalani et al., 2007) and delayed monsoon onset 

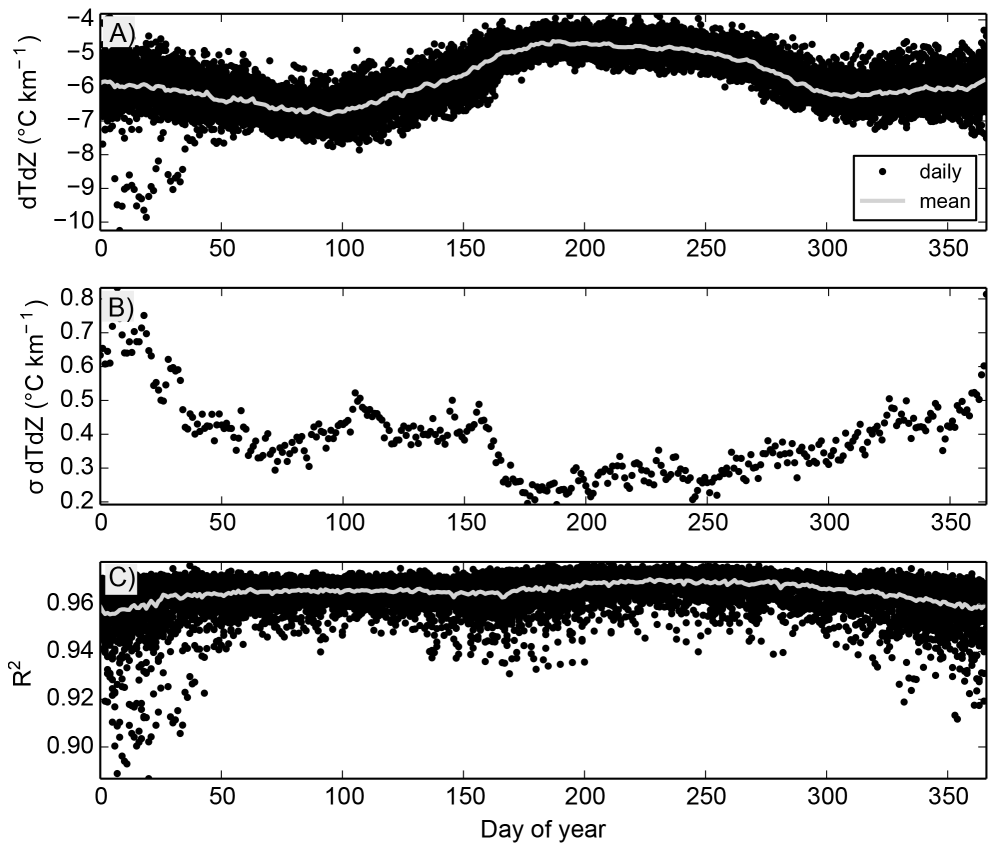

Figure 3. (a) Vertical temperature gradients $\left(\gamma_{T}\right)$ by day of year (DOY) for all years (black) calculated from APHRODITE (1961-2007) temperature fields and resampled SRTM data, with period mean in grey, (b) daily standard deviation $(\sigma)$ of $\gamma_{T}$, and (c) mean daily coefficient of determination $\left(R^{2}\right)$ calculated from the linear regression of resampled SRTM elevations and APRHODITE cell temperatures. All temperature/elevation regressions are significant.

(Ashfaq et al., 2009; Mölg et al., 2012) in the 21st century, while the change in total annual precipitation is mixed. In the Himalayas, the CMIP5 ensemble shows projected changes in precipitation between -8 to $+15 \%$ (Lutz et al., 2013; Palazzi et al., 2013).

\subsection{Models of glacier change}

In spite of the recent observed changes in glaciers in the Everest region, the reported climatic trends, the expected glacier sensitivity to climatic change, and the importance of glacier water resources in the region, few studies have attempted to model the historical or future response of these glaciers to climate change (Immerzeel et al., 2012, 2013). Empirical mass balance and snowmelt and ice melt models have been developed from field observations (Ageta and Higuchi, 1984; Ageta and Kadota, 1992; Nakawo et al., 1999) and reanalysis products (Fujita and Nuimura, 2011; Rasmussen, 2013), and such approaches have been used to quantify glacier contributions to streamflow (Racoviteanu et al., 2013; Nepal et al., 2013). Projections of higher ELAs in the region (Fujita and Nuimura, 2011) and volume areascaling approaches (Shi and Liu, 2000; Cogley, 2011) indicate continued mass wastage in the future, yet impact studies on the response of glaciers to climate change require models that link mass balance processes with representations of glacier dynamics.
One- and two-dimensional models of glacier dynamics have been applied previously to the Khumbu Glacier (Naito et al., 2000) and the East Rongbuk Glacier (Zhang et al., 2013), respectively. However, these and higher-order models of glacier dynamics are severely limited by input data availability (e.g. bed topography, ice temperatures, basal water pressure) and uncertainties in key model parameters, and have not been applied at catchment scales in the region. Debris-covered glaciers, which compose $25 \%$ of total glacierized area, present additional modelling challenges, and validation is also limited by the availability of data. Relatively coarse methods of simulating future glacier change (e.g. Stahl et al., 2008) can be improved by applying models that can reasonably simulate key glaciological parameters (thickness, velocity, and mass redistribution).

The main objective of this study is to apply a glacier mass balance and redistribution model to the Dudh Koshi River basin, Nepal. To accomplish this, we (1) develop downscaling routines for temperature and precipitation; (2) calibrate and test the model with available field and remotely sensed observations; and (3) explore the modelled sensitivity of glaciers in the Everest region to future climate change with a suite of temperature and precipitation changes from the CMIP5 ensemble. 


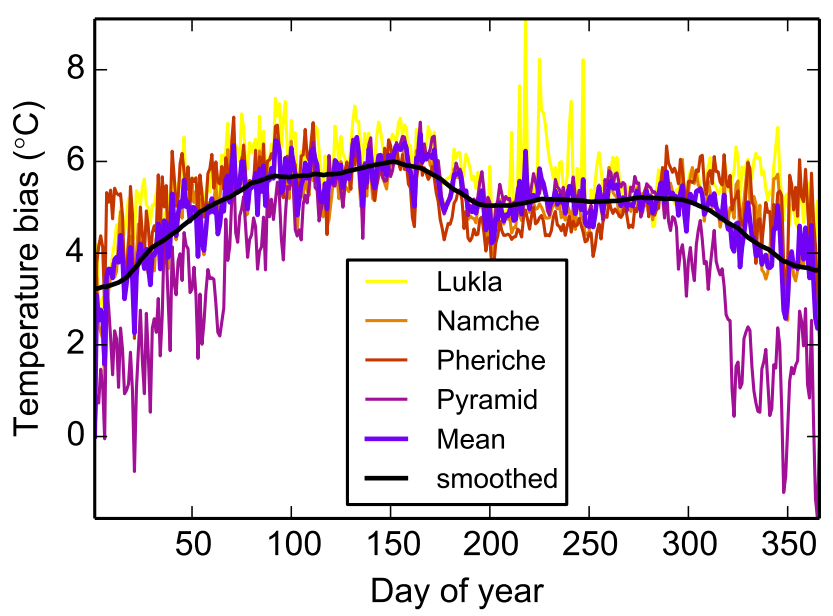

Figure 4. Average daily temperature bias (estimated - observed) for four EVK2CNR sites (2003-2007), their arithmetic mean, and a smoothed function used as a daily bias correction.

\section{Data and methods}

\subsection{Daily climate fields}

There are few observations of temperature and precipitation in the basin, and no temperature records longer than 15 years are available. To generate high-resolution fields of temperature $(T)$ and precipitation $(P)$ as inputs to the model, we use data from the APHRODITE (Asian Precipitation - HighlyResolved Observational Data Integration Towards Evaluation of Water Resources) project (Yatagai et al., 2009, 2012). APHRODITE products have been previously used to test regional climate model simulations in northern India (Mathison et al., 2013) and the western Himalaya (Dimri et al., 2013), and to compare precipitation data sets in the Himalayan region (Palazzi et al., 2013). For this study, we use APHRODITE $T$ fields (V1204R1) that are based on daily station anomalies from climatological means, interpolated on $0.05^{\circ}$ grids and then resampled to $0.25^{\circ}$ fields, and we refer to Yatagai et al. (2012) for more details. The APHRODITE $P$ fields (V1101) are based on a similar technique using precipitation ratios but incorporate a weighted interpolation scheme based on topographical considerations (Yatagai et al., 2012).

To generate high-resolution fields of $T$ and $P$ for the glacier mass balance model, we extract a $196(14 \times 14)$ grid cell subset of the daily APHRODITE $T$ and $P$ fields that covers the Koshi basin (Fig. 1). Approximate elevations for each $0.25^{\circ}$ grid cell are extracted from a resampled gap-filled Shuttle Radar Topography Mission (SRTM V4; Farr et al., 2007) digital elevation model (DEM). Based on this subset we derive relations between elevation and temperature and precipitation respectively at coarse resolution. We then use these relations in combination with the $90 \mathrm{~m}$ SRTM DEM to produce high-resolution daily climate fields.

\subsubsection{Temperature}

Downscaled temperature fields at daily $90 \mathrm{~m}$ resolution are computed as

$T_{Z}=\gamma_{T} Z+T_{0}-C_{\mathrm{DOY}}$,

where $\gamma_{T}$ is the daily vertical temperature gradient (Fig. 3) derived from the $0.25^{\circ}$ APRHODITE temperatures and SRTM elevations, $T_{0}$ is the daily temperature intercept, and $C_{\text {DOY }}$ is a bias correction based on the day of year (Fig. 4). The bias-correction factor is computed from the mean daily temperature difference between observed and estimated mean daily temperatures at four stations operated by the Italian Everest-K2-National Research Centre (EVK2CNR; Fig. 1, Table 1), and it ranges from 3 to $6{ }^{\circ} \mathrm{C}$. The EVK2CNR stations are independent of the APHRODITE product.

\subsubsection{Precipitation}

To calculate high-resolution daily precipitation fields from the APHRODITE subset, we prescribe daily precipitationelevation functions from the $0.25^{\circ}$ APHRODITE precipitation fields and resampled SRTM data. For each day, we calculate the mean precipitation in $500 \mathrm{~m}$ elevation bins $\left(\bar{P}_{500}\right)$ and prescribe a fitted linear interpolation function to estimate precipitation on the $90 \mathrm{~m}$ SRTM DEM (Fig. 5).

As APHRODITE fields are based on interpolated station data (Yatagai et al., 2012), there is a large uncertainty in the precipitation at high elevations. Independent tests of the precipitation downscaling approach were conducted by comparing precipitation observations from the EVK2CNR stations with precipitation estimated using the station elevation and the daily precipitation-elevation functions (Fig. 6). As EVK2CNR stations are not capable of measuring solid precipitation (Wagnon et al., 2013), we only examine days where only liquid precipitation $(T>0)$ is expected.

While orographic forcing of moist air masses typically produces increased precipitation with elevation, in very highelevation regions (i.e. those greater than $4000 \mathrm{~m}$ ) both observations and models indicate that precipitation totals will decrease above a certain elevation (Harper and Humphrey, 2003; Mölg et al., 2009). This is due in part to the drying effect from upwind orographic forcing but is also related to the low column-averaged water vapour content indicated by the Clausius-Clapeyron relation. Given that there are no precipitation observations at elevations above $5300 \mathrm{~m}$, and available evidence suggests that precipitation will likely decrease at high elevations, we scale estimated precipitation using a correction factor $p_{\text {cor }}$ :

$P(Z)=\left\{\begin{aligned} P(Z), & Z<Z_{\mathrm{c}} \\ P(Z) p_{\text {cor }}, & Z_{\mathrm{c}} \leq Z<Z_{\mathrm{m}} \\ 0, & Z \geq Z_{\mathrm{m}},\end{aligned}\right.$

where $p_{\text {cor }}$ decreases from 1 at the height of a calibrated threshold elevation $\left(Z_{\mathrm{c}}\right.$; Table 2$)$ to 0 at $Z_{\mathrm{m}}$, set here to $7500 \mathrm{~m}:$ 

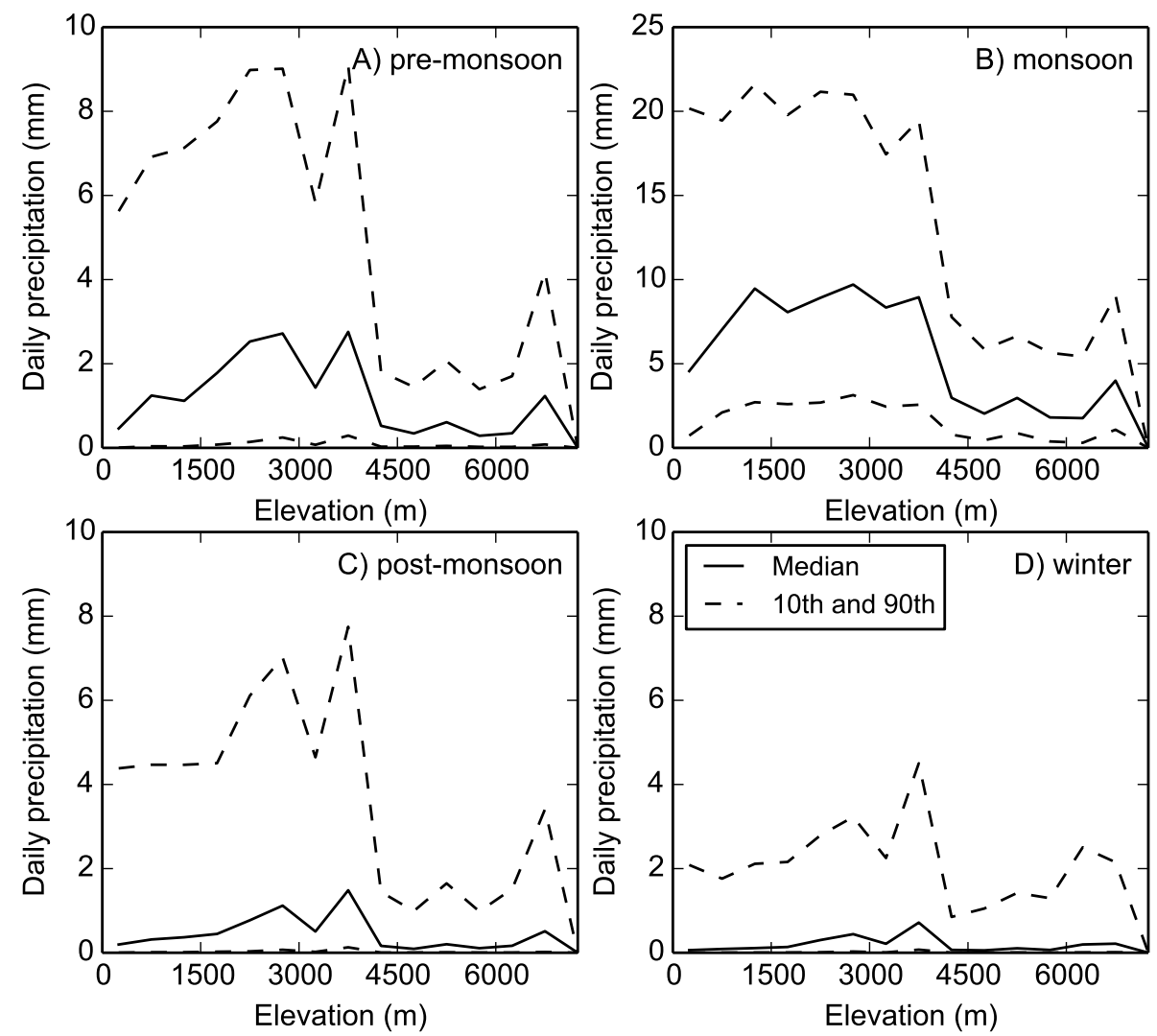

Figure 5. APHRODITE precipitation (1961-2007) binned by elevation for pre-monsoon (a), monsoon (b), post-monsoon (c), and winter (d). Median, 10th percentile, and 90th percentile of daily precipitation are shown. Note different scale for panel (b).

$p_{\text {cor }}=1-\left(Z-Z_{\mathrm{c}}\right) /\left(Z_{\mathrm{m}}-Z_{\mathrm{c}}\right)$.

Above $7500 \mathrm{~m}$, we assume that precipitation amounts minus wind erosion and sublimation (Wagnon et al., 2013) are likely to be negligible. The total area above $7500 \mathrm{~m}$ represents only $1.2 \%$ of the total basin area.

\subsection{Glacier mass balance and redistribution}

Following the methods of Immerzeel et al. (2012) and Immerzeel et al. (2013), daily accumulation and ablation between 1961 and 2007 are estimated from the gridded $T$ and $P$ fields. All calculations are based on the $90 \mathrm{~m}$ SRTM DEM. Daily accumulation is equal to the total precipitation when $T<0{ }^{\circ} \mathrm{C}$, which is a conservative threshold with respect to other studies that have used values of 1.5 or $2{ }^{\circ} \mathrm{C}$ (Oerlemans and Fortuin, 1992), but this value has been used in previous Himalayan models (Immerzeel et al., 2012). Daily ablation is estimated using a modified degree-day factor $\left(\mathrm{ddf}_{\mathrm{M}}\right)$ that varies with DEM-derived aspect $(\theta)$ and surface type:

$\operatorname{ddf}_{\mathrm{M}}=\operatorname{ddf}\left(1-R_{\exp } \cos \theta\right)$,

where ddf is the initial melt factor (in $\mathrm{mm}^{\circ} \mathrm{C}^{-1} \mathrm{~d}^{-1}$ ), and $R_{\exp }$ is a factor which quantifies the aspect (or exposure) dependence of ddf (Immerzeel et al., 2012). Initial values for melt factors for snow, ice, and debris-covered glaciers (Azam et al., 2014) are given in Table 2. The extent of debriscovered glaciers was extracted from the ICIMOD (2011) glacier inventory.

To redistribute mass from accumulation to ablation areas, we use a simplified flow model which assumes that basal sliding is the principal process for glacier movement and neglects deformational flow. While cold-based glaciers have been observed on the Tibetan Plateau (Liu et al., 2009), warm-based glaciers and polythermal regimes have been identified on the monsoon-influenced southern slopes of the Himalayas (Mae et al., 1975; Ageta and Higuchi, 1984; Kääb, 2005; Hewitt, 2007). Our assumption in this case is a necessary simplification of the sliding and deformational components of ice flow, which have not yet been modelled at the basin scale in the Himalayas.

Glacier motion is modelled as slow, viscous flow using Weertman's sliding law (Weertman, 1957), which describes glacier movement as a combination of both pressure melting and ice creep near the glacier bed. Glacier flow is assumed to be proportional to the basal shear stress $\left(\tau_{\mathrm{b}}, \mathrm{Pa}\right)$ :

$\tau_{\mathrm{b}} \approx v^{2} R u^{\frac{2}{n+1}}$. 

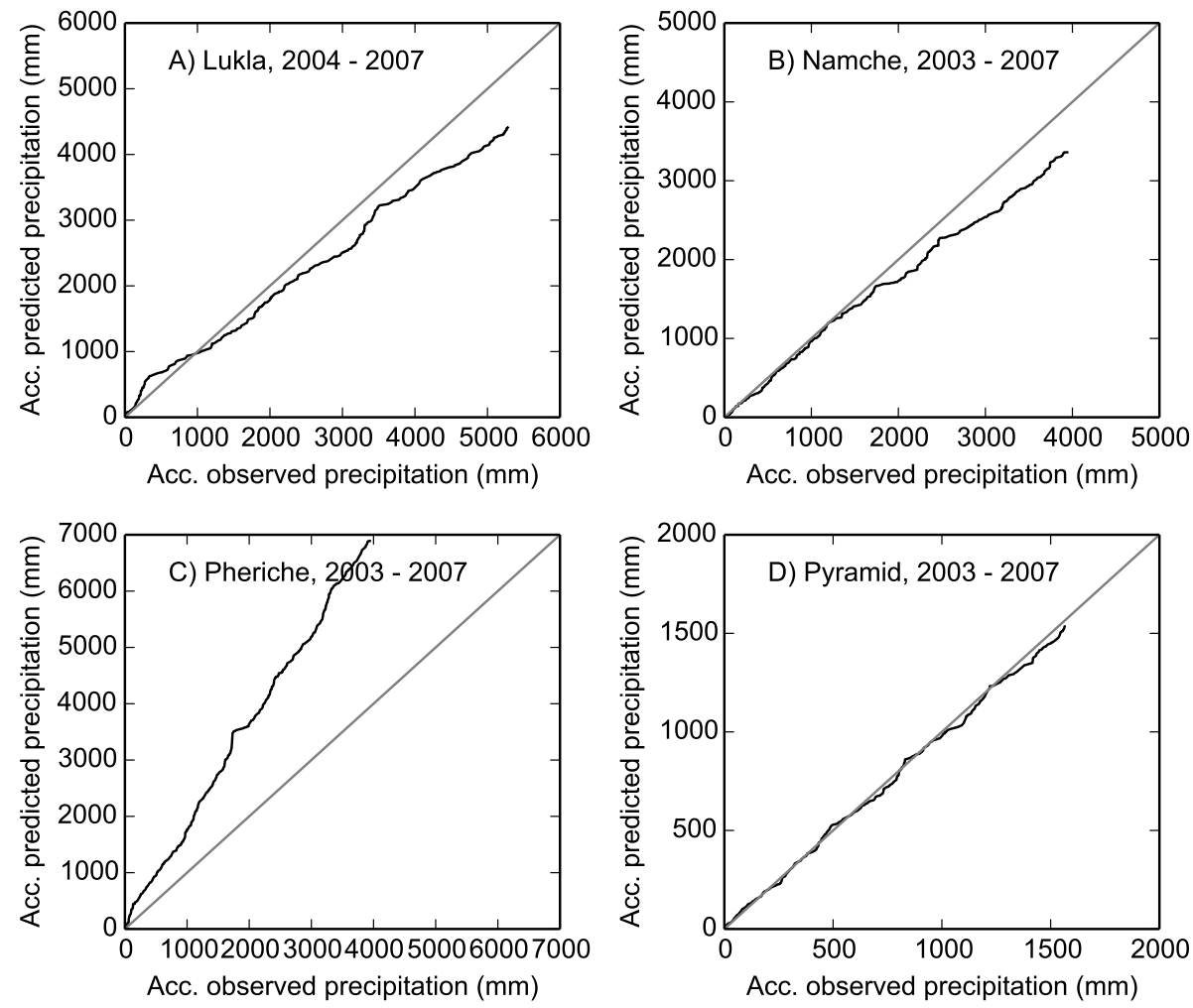

Figure 6. Accumulated observed and predicted precipitation at the EVK2CNR sites. Days where $T<0$ or precipitation observations were missing were excluded from the analyses.

Table 2. Fixed and calibrated model parameters, with initial values, range, and final calibrated values. Degree-day factors (ddf) varied within 1 standard deviation (SD) (Supplementary Information of Immerzeel et al., 2010).

\begin{tabular}{llllll}
\hline Parameter & Description & Units & $\begin{array}{l}\text { Initial } \\
\text { value }\end{array}$ & Range & $\begin{array}{l}\text { Calibrated } \\
\text { value }\end{array}$ \\
\hline$\rho$ & Ice density & $\mathrm{kg} \mathrm{m}^{-3}$ & 916.7 & - & - \\
$g$ & Gravitational acceleration & $\mathrm{m} \mathrm{s} \mathrm{s}^{-2}$ & 9.81 & - & - \\
$\tau_{0}$ & Equilibrium shear stress & $\mathrm{N} \mathrm{m}^{-2}$ & 80000 & - & - \\
$\nu$ & Bedrock roughness & unitless & 0.1 & - & - \\
$T_{\mathrm{S}}$ & Snow/rain limit & ${ }^{\circ} \mathrm{C}$ & 0 & - & - \\
$\gamma_{T}$ & Daily vertical temperature gradient & ${ }^{\circ} \mathrm{C} \mathrm{m}^{-1}$ & variable & - & - \\
$C_{\mathrm{DOY}}$ & Temperature bias correction & ${ }^{\circ} \mathrm{C}$ & variable & - & - \\
$R_{\mathrm{exp}}$ & Aspect dependence of ddf & $\mathrm{unitless}$ & 0.2 & - & - \\
$\beta_{\mathrm{TH}}$ & Threshold avalanching angle & ${ }^{\circ}$ & 50 & - & $1.51 \times 10^{8}$ \\
$R$ & Material roughness coefficient & $\mathrm{N} \mathrm{m}^{-2} \mathrm{~s}^{1 / 3}$ & $1.80 \times 10^{9}$ & $\pm 5.00 \times 10^{8}$ & 1.7 \\
$\mathrm{ddf}_{\mathrm{C}}$ & Clean ice melt factor & $\mathrm{mm}^{\circ} \mathrm{C}^{-1} \mathrm{~d}^{-1}$ & 8.63 & $\pm 1 \mathrm{SD}$ & 9.7 \\
$\mathrm{ddf}_{\mathrm{D}}$ & Debris-covered ice melt factor & $\mathrm{mm}^{\circ} \mathrm{C}^{-1} \mathrm{~d}^{-1}$ & 3.34 & $\pm 1 \mathrm{SD}$ & 4.6 \\
$\mathrm{ddf}_{\mathrm{K}}$ & Khumbu Glacier melt factor & $\mathrm{mm}^{\circ} \mathrm{C}^{-1} \mathrm{~d}^{-1}$ & 6.7 & & 8.6 \\
$\mathrm{ddf}_{\mathrm{S}}$ & Snowmelt factor & $\mathrm{mm}^{\circ} \mathrm{C}^{-1} \mathrm{~d}^{-1}$ & 5.3 & $\pm 1 \mathrm{SD}$ & 5.4 \\
$Z_{\mathrm{C}}$ & Height of precipitation maximum & $\mathrm{m} \mathrm{a.s.1.}$ & 6000 & \pm 500 & 6268 \\
\hline
\end{tabular}




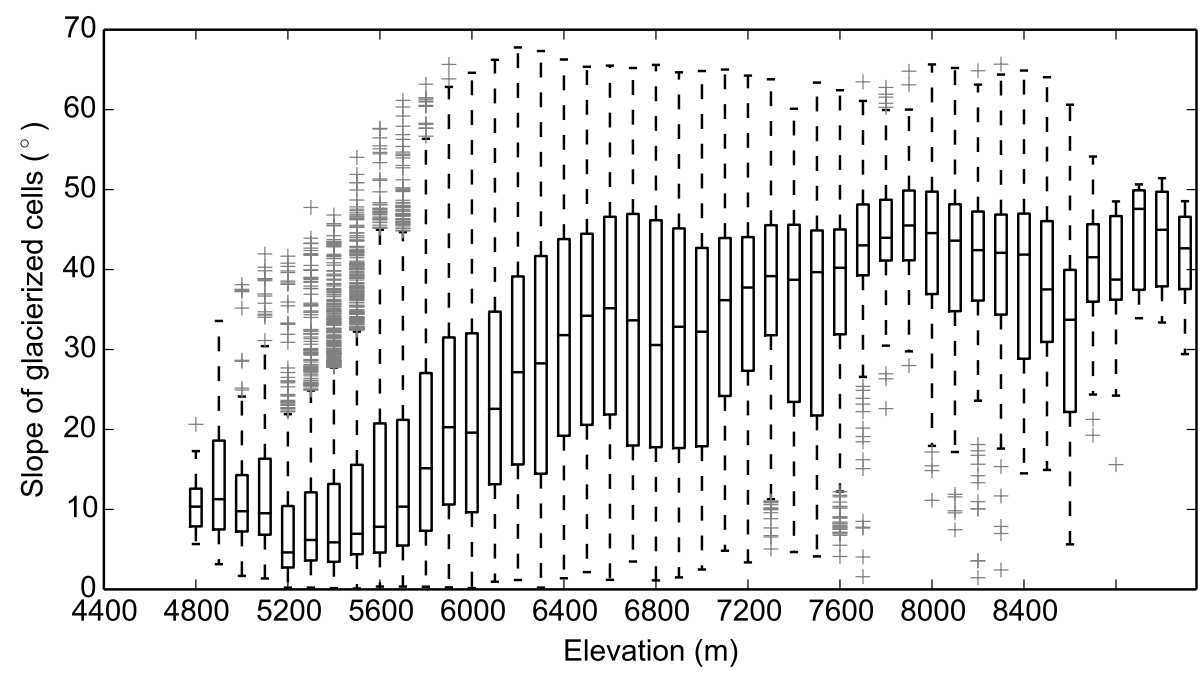

Figure 7. Boxplots of the slope of glacierized pixels in the Dudh Koshi basin, grouped by $100 \mathrm{~m}$ elevation bands. The boundaries of each box indicate the upper and lower quartiles, while the middle line of the box shows the median value. Whisker ends indicate the maximum (minimum) values excluding outliers, which are defined as more (less) than 3/2 times the upper (lower) quartile. Slope values were extracted from the SRTM $90 \mathrm{~m}$ DEM and glacier inventory from ICIMOD (2011).

Here, $v$ (unitless) is a measure of bedrock roughness, $R$ $\left(\mathrm{Pa} \mathrm{m}^{-2} \mathrm{~s}\right)$ is a material roughness coefficient, $u$ is the sliding speed $\left(\mathrm{m} \mathrm{s}^{-1}\right)$ and $n$ (unitless) is the creep constant of Glen's flow law, here assumed to equal 3 (Glen, 1955). The roughness of the bedrock $(v)$ is defined as the dimension of objects on the bedrock divided by the distance between them. Smaller values for $v$ indicate more effective regelation. $R$ is a material roughness coefficient that controls the viscous shearing (Fowler, 2010). Basal shear stress $\left(\tau_{\mathrm{b}}\right)$ is defined as

$\tau_{\mathrm{b}}=\rho g H \sin \beta$,

where $\rho$ is ice density $\left(\mathrm{kg} \mathrm{m}^{-3}\right), g$ is gravitational acceleration $\left(\mathrm{m} \mathrm{s}^{-2}\right), H$ is ice thickness $(\mathrm{m})$, and $\beta$ is surface slope $\left(^{\circ}\right)$. We assume that motion occurs only when basal shear stress exceeds the equilibrium shear stress $\left(\tau_{0}=\right.$ $80000 \mathrm{~N} \mathrm{~m}^{-2}$; Immerzeel et al., 2012), and combine Eqs. (5) and (6) to derive the glacier velocity:

$u^{\frac{2}{n+1}}=\frac{\max \left(0, \tau_{\mathrm{b}}-\tau_{0}\right)}{v^{2} R}$.

For each time step, glacier movement in each cell is thus modelled as a function of slope, ice thickness, and assumed bedrock roughness. The total outgoing ice flux at each time step is then determined by the glacier velocity, the horizontal resolution, and the estimated ice depth. Ice transported out of a specific cell is distributed to all neighbouring downstream cells based on slope, with steeper cells receiving a greater share of the ice flux.

As avalanches can contribute significantly to glacier accumulation in steep mountainous terrain (Inoue, 1977; Scherler et al., 2011b), the model incorporates an avalanching component which redistributes accumulated snowfall (Bernhardt and Schulz, 2010). The approach assumes that all snow in a given cell is transported to the downstream cell with the steepest slope whenever snow-holding depth and a minimum slope angle is exceeded. The snow-holding depth is deep in flat areas and shallow in steep areas and decreases exponentially with increasing slope angle.

Based on field observations and an analysis of the slopes of glacierized pixels in the catchment (Fig. 7), we assign a threshold avalanching angle $\left(\beta_{\mathrm{TH}}\right)$ of $50^{\circ}$. Change in ice thickness at each time step is thus the net result of ice flow through the cell, ablation, and accumulation from both precipitation and avalanching. Changes in glacier area and volume are calculated at daily time steps, and pixels with a snow water equivalent greater than $0.2 \mathrm{~m}$ w.e. are classified as glacier. The model does not assume steady-state conditions, and reported changes in volume and area thus represent transient states within the model.

\subsection{Model initialization}

Initial ice thickness for each glacierized grid cell is derived from Eq. (6):

$H=\frac{\tau_{0}}{\rho g \sin \beta}$,

with a minimum prescribed slope of $1.5^{\circ}$. We use $\tau_{0}$ here, as the actual basal shear stress depends on the ice thickness. In the Dudh Koshi basin, Eq. (8) produces a total estimated glacier volume of $32.9 \mathrm{~km}^{3}$, based on the ICIMOD (2011) glacier inventory and SRTM DEM. While volumearea scaling relations are uncertain (Frey et al., 2013), empirical relations from Huss and Farinotti (2012) and Radić and Hock (2010) applied to individual glaciers generate basin- 
wide volume estimates of 31.9 and $27.5 \mathrm{~km}^{3}$, respectively, which lends some support to the approach used here.

From the initial ice thicknesses we estimate glacier thicknesses and extents in 1961 by driving the glacier mass balance and redistribution model with modified APHRODITE temperature fields. To simulate the observed climate in the region prior to 1961 , temperatures in the initialization run are decreased by $-0.025^{\circ} \mathrm{C} \mathrm{yr}^{-1}$ (Shrestha and Aryal, 2011), for a total decrease of $-1.2{ }^{\circ} \mathrm{C}$ over the 47 -year initialization period. Precipitation is left unchanged in the model initialization, and we use uncalibrated model parameters (Table 2).

Mass change at the end of the 47-year initialization period is close to zero, indicating that near-equilibrium conditions have been realized. Additional runs of the initialization period, with temperatures fixed at $-1.2{ }^{\circ} \mathrm{C}$, yield relatively small changes in glacier thickness (Fig. 8). However, it is possible that there are significant uncertainties in our estimates of initial (1961) thicknesses and extents, given the forcings and parameter set used, and the lag in glacier geometry responses to climate forcings.

\subsection{Model calibration}

From the modelled 1961 ice thicknesses and extents, the model is calibrated with six parameters: degree-day factors for clean ice $\left(\mathrm{ddf}_{\mathrm{C}}\right)$, debris-covered ice $\left(\mathrm{ddf}_{\mathrm{I}}\right)$, snow $\left(\mathrm{ddf}_{\mathrm{S}}\right)$, and debris covered ice on the Khumbu Glacier $\left(\mathrm{ddf}_{\mathrm{K}}\right)$, material roughness coefficient $R$, and elevation of the precipitation maximum $Z_{C}$ (Table 2). Initial simulations showed anomalous flow velocities of the Khumbu Glacier, which may be due to the assumption that basal sliding is the main process of movement. This may not hold given the steep icefall above the glacier tongue and the large high-altitude accumulation area. We have corrected for this by calibrating a specific melt factor for this glacier, though improved representation of the glacier dynamics should reduce the need for a separate $\mathrm{ddf}_{\mathrm{K}}$. Twenty parameter sets (Table 3 ) were developed by varying the six calibration factors within specified ranges (Table 2). Initial values for each parameter were selected from published studies.

For each of the 20 runs (Table 4), we quantify the model skill by scoring (a) modelled and observed glacier extents at the termini of four large glaciers in the catchment (ICIMOD, 2011), (b) the geodetically derived mean basin-wide glacier mass balance of $-0.40 \mathrm{~m}$ w.e. $\mathrm{yr}^{-1}$ over the period 1992-2008 (Nuimura et al., 2012), (c) a mean velocity of $10 \mathrm{~m} \mathrm{yr}^{-1}$ for debris-covered glaciers (Nakawo et al., 1999; Quincey et al., 2009), and (d) the total glacierized area in $2007\left(410 \mathrm{~km}^{2}\right.$; ICIMOD, 2011). These tests gauge the ability of the model to accurately reproduce key glacier parameters: extent, mass change, and velocity. Scores are derived from the difference between modelled and observed quantities, with a score of zero indicating a perfect match. Scores for all four metrics are added to obtain an overall ranking of the 20 parameter sets and are weighted equally.
The glacier extent score denotes the relative deviation from a perfect match of the four large glacier termini at the end of the calibration period (Fig. 1). There are eight test polygons in total that include ice-covered and adjacent icefree areas. For example, if only $20 \%$ of the glacier polygons in Fig. 1 are ice covered then the score equals 0.8. The mass balance score is based on the relative offset from the catchment mean mass balance of -0.40 m w.e. $\mathrm{yr}^{-1}$ over the period 1992-2008:

$S_{\mathrm{MB}}=\left|\left(B_{\mathrm{m}} /-0.4\right)-1\right|$.

If the modelled mean mass balance $\left(B_{\mathrm{m}}\right)$ equals $-0.20 \mathrm{~m}$ w.e. $\mathrm{yr}^{-1}$, then the mass balance score $\left(S_{\mathrm{MB}}\right)$ is 0.5 . The total ice area score is based on the departure from the total glacierized area at the end of the simulation $\left(410 \mathrm{~km}^{2}\right.$, ICIMOD, 2011). If the simulated ice extent is $300 \mathrm{~km}^{2}$, then the score is $0.27((410-300) / 410)$. Finally the flow velocity score quantifies the deviation from a mean glacier velocity of debris-covered tongues from 1992 to $2008\left(10 \mathrm{~m} \mathrm{yr}^{-1}\right)$. For example, if the average simulated flow velocity is $2 \mathrm{~m} \mathrm{yr}^{-1}$, then the score is 0.8 . The final score used to select the optimal parameter set is a simple addition of the four scores.

\subsection{Model validation}

Temperature and precipitation fields developed for this study were tested independently using point observations of mean daily temperature and total daily precipitation at the four EVK2NCR sites. We calculate mean bias error (MBE) and root mean square error (RMSE) to evaluate the skill of the elevation-based downscaling.

To validate the calibrated glacier mass balance and redistribution model, model outputs are compared against the following independent data sets:

- ice thickness profiles derived from ground-penetrating radar (GPR) at Mera Glacier (Wagnon et al., 2013) and Changri Nup Glacier (Vincent, unpublished data);

- annual mass balance and glacier mass balance gradients calculated from surface observations at Mera Glacier (Wagnon et al., 2013);

- decadal glacier extents (1990, 2000, 2010) extracted from Landsat imagery (Bajracharya et al., 2014b);

- basin-wide mean annual mass balance from 2000 to 2011 (Gardelle et al., 2013), and from 1970 to 2007 (Bolch et al., 2011).

\subsection{Glacier sensitivity to future climate change}

To examine the sensitivity of modelled glaciers to future climate change, we drive the calibrated model with temperature and precipitation anomalies prescribed from eight CMIP5 

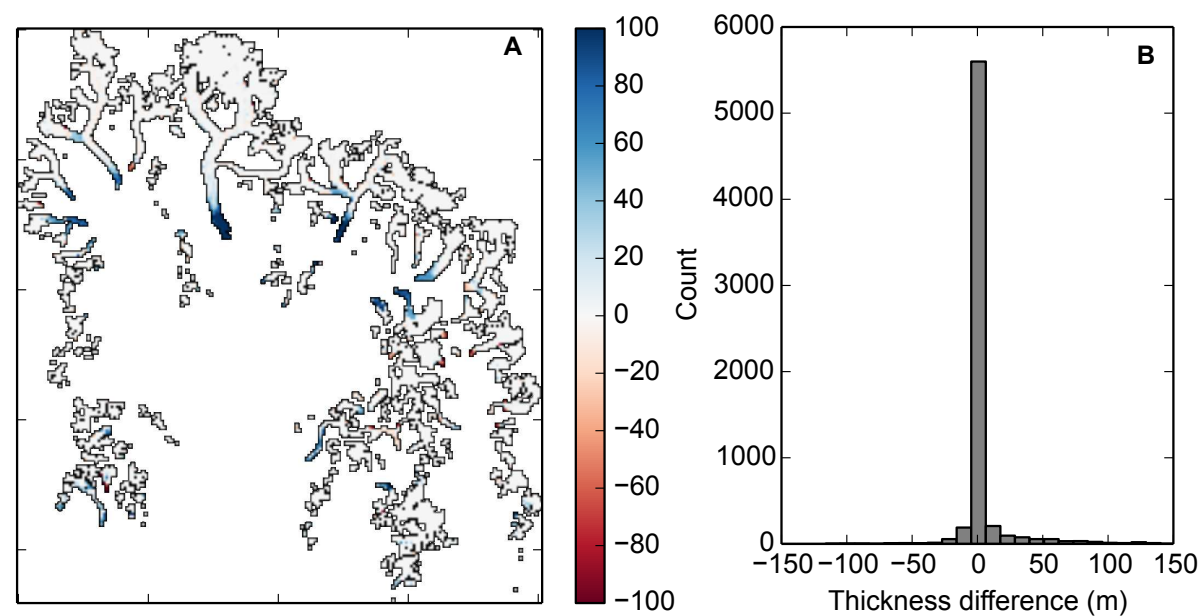

Figure 8. (a) Differences in modelled ice thickness (in $\mathrm{m}$ ) between the end of the first initialization run (47 years) and after an additional 94 years of simulation with $\mathrm{d} T=-1.2^{\circ} \mathrm{C}$. (b) Histogram of differences in modelled ice thickness.

Table 3. Parameter sets used in the calibration procedure. Degree-day factors $\left(\operatorname{ddf}_{n}\right)$ are given in units of $\mathrm{mm}^{\circ} \mathrm{C}^{-1} \mathrm{~d}^{-1}, R$ is unitless, and $Z_{\mathrm{C}}$ is in $\mathrm{m}$. Mean $(\bar{x})$ and standard deviation $(\sigma)$ are given at the bottom of the table.

\begin{tabular}{lrrrrrr}
\hline Run & ddf $_{\mathrm{C}}$ & ddf $_{\mathrm{D}}$ & ddf $_{\mathrm{K}}$ & ddf $_{\mathrm{S}}$ & $R$ & $Z_{\mathrm{C}}$ \\
\hline 1 & 10.1 & 2.4 & 5.7 & 5.1 & 965538934 & 5948 \\
2 & 9.8 & 3.7 & 6.8 & 4.6 & 862185519 & 5974 \\
3 & 9.2 & 4.1 & 8.5 & 3.6 & 1326340408 & 5544 \\
4 & 8.8 & 1.7 & 5.3 & 5.7 & 2115148902 & 6392 \\
5 & 9.7 & 4.6 & 8.6 & 5.4 & 1507211339 & 6268 \\
6 & 8.9 & 1.9 & 6.8 & 4.3 & 1757035837 & 5712 \\
7 & 9.3 & 3.6 & 7.3 & 6.6 & 1602852068 & 5810 \\
8 & 8.9 & 2 & 7 & 5.3 & 1891517886 & 7175 \\
9 & 9.3 & 2.9 & 8.2 & 5.7 & 965461867 & 6663 \\
10 & 8.1 & 3.1 & 9 & 5.8 & 1966902971 & 6339 \\
11 & 9.3 & 4.1 & 7 & 5.1 & 2119160369 & 5804 \\
12 & 10.1 & 3.3 & 6.4 & 4.7 & 1183544033 & 5774 \\
13 & 10.2 & 2.2 & 5.7 & 5.1 & 2027971886 & 5960 \\
14 & 9.3 & 5.2 & 6.6 & 6.4 & 1642592045 & 5887 \\
15 & 8.5 & 3.2 & 6.7 & 3.9 & 1674708607 & 5466 \\
16 & 8.1 & 4.3 & 4.2 & 5.5 & 1278943171 & 6877 \\
17 & 10.2 & 3.5 & 5.4 & 5.6 & 1687134148 & 6314 \\
18 & 10.7 & 2 & 6.2 & 5.3 & 1920883676 & 6270 \\
19 & 7.6 & 2.9 & 7.2 & 4.6 & 2402645369 & 5586 \\
20 & 10.8 & 3.5 & 6 & 6.4 & 1885850339 & 5673 \\
$\bar{x}$ & 9.3 & 3.2 & 6.7 & 5.2 & 1639181469 & 6072 \\
$\sigma$ & 0.87 & 0.98 & 1.23 & 0.8 & 428282810 & 459 \\
\hline & & & & & & \\
\hline
\end{tabular}

climate simulations that represent cold/warm and dry/wet end-members (Table 5; Immerzeel et al., 2013). Decadal $T$ and $P$ anomalies relative to 1961-1990 are extracted from the CMIP5 end-members. Temperature trends are strong in all CMIP5 simulations, with ensemble mean temperature increases to 2100 as great as $+8^{\circ} \mathrm{C}$ in late winter and early spring (January-April). Precipitation anomalies do not show any significant trends and vary between 0.4 and 1.8 times the baseline period. Uncertainties in our scenarios of future climate change are examined through the mean and standard deviation of modelled ice areas and volumes derived from the eight CMIP5 models. As the model is empirically based and we assume only changes in $T$ and $P$ (all other state and input variables remain unchanged), we stress that the resulting glacier change realizations are a reflection of the modelled sensitivity to climate change, as opposed to physically based projections. 
Table 4. Scores (unitless) from the 20 calibration runs versus independent calibration data. Calibration targets were observed extents of four large termini, basin-wide net mass balance of $-0.40 \mathrm{~m}$ (Nuimura et al., 2012), total glacier area of $410 \mathrm{~km}^{2}$ in 2010 (ICIMOD, 2011), and mean velocity of $10 \mathrm{~m} \mathrm{yr}^{-1}$ on debris-covered tongues (Quincey et al., 2009). Mean and standard deviation $(\sigma)$ of scores are provided at the bottom of the table, and scores for the selected run are in bold.

\begin{tabular}{lccccc}
\hline Run & Terminus extents & $B_{\mathrm{a}}$ & Total area & Velocity & Total score \\
\hline 1 & 0.20 & 0.46 & 0.04 & 3.44 & 4.14 \\
2 & 0.19 & 0.31 & 0.03 & 2.78 & 3.31 \\
3 & 0.19 & 0.26 & 0.01 & 0.34 & 0.79 \\
4 & 0.19 & 0.69 & 0.04 & 0.38 & 1.30 \\
$\mathbf{5}$ & $\mathbf{0 . 1 7}$ & $\mathbf{0 . 1 9}$ & $\mathbf{0 . 0 6}$ & $\mathbf{0 . 0 5}$ & $\mathbf{0 . 4 7}$ \\
6 & 0.20 & 0.58 & 0.01 & 0.75 & 1.54 \\
7 & 0.18 & 0.23 & 0.09 & 0.10 & 0.59 \\
8 & 0.19 & 0.70 & 0.03 & 0.88 & 1.80 \\
9 & 0.20 & 0.46 & 0.05 & 3.13 & 3.83 \\
10 & 0.18 & 0.45 & 0.05 & 0.01 & 0.69 \\
11 & 0.18 & 0.24 & 0.05 & 0.47 & 0.94 \\
12 & 0.19 & 0.33 & 0.04 & 1.21 & 1.76 \\
13 & 0.19 & 0.52 & 0.04 & 0.08 & 0.84 \\
14 & 0.17 & 0.05 & 0.09 & 0.44 & 0.75 \\
15 & 0.19 & 0.39 & 0.00 & 0.08 & 0.65 \\
16 & 0.18 & 0.44 & 0.04 & 0.72 & 1.37 \\
17 & 0.18 & 0.36 & 0.06 & 0.02 & 0.63 \\
18 & 0.19 & 0.56 & 0.05 & 0.37 & 1.18 \\
19 & 0.19 & 0.46 & 0.02 & 0.36 & 1.03 \\
20 & 0.18 & 0.20 & 0.10 & 0.37 & 0.85 \\
$\bar{x}$ & 0.19 & 0.39 & 0.04 & 0.80 & 1.42 \\
$\sigma$ & 0.01 & 0.18 & 0.03 & 0.87 & 0.90 \\
\hline
\end{tabular}

Table 5. Projected mean annual temperature and precipitation changes from 1961-1990 to 2021-2050, extracted from RCP4.5 and RCP8.5 CMIP5 runs. See Supplementary Information from Immerzeel et al. (2013) for more information.

\begin{tabular}{llcccc}
\hline Scenario & Description & $\mathrm{d} P(\%)$ & $\mathrm{d} T\left({ }^{\circ} \mathrm{C}\right)$ & Model & Ensemble \\
\hline RCP4.5 & Dry, Cold & -3.2 & 1.5 & HADGEM2-CC & r1i1p1 \\
RCP4.5 & Dry, Warm & -2.3 & 2.4 & MIROC-ESM & r1i1p1 \\
RCP4.5 & Wet, Cold & 12.4 & 1.3 & MRI-CGCM3 & r1i1p1 \\
RCP4.5 & Wet, Warm & 12.1 & 2.4 & IPSL-CM5A-LR & r3i1p1 \\
\hline \multirow{2}{*}{ RCP8.5 } & Dry, Cold & -3.6 & 1.7 & HADGEM2-CC & r1i1p1 \\
RCP8.5 & Dry, Warm & -2.8 & 3.1 & IPSL-CM5A-LR & r2i1p1 \\
RCP8.5 & Wet, Cold & 15.6 & 1.8 & CSIRO-MK3-60 & r1i1p1 \\
RCP8.5 & Wet, Warm & 16.4 & 2.9 & CAN-ESM2 & r2i1p1 \\
\hline
\end{tabular}

\section{Results}

\subsection{APHRODITE downscaling}

Daily vertical temperature gradients calculated from the APHRODITE temperature fields and resampled SRTM range from -0.010 to $-0.004{ }^{\circ} \mathrm{C} \mathrm{m}^{-1}$ and are highly significant (Fig. 3). Calculated $\gamma_{T}$ values are most negative in the premonsoon (mid-April) and least negative during the active phase of the summer monsoon (mid-June to late August). This is likely a function of the increased moisture advection in the monsoon and pre-monsoon periods, which re- sults in a less negative moist adiabatic lapse rate. These findings are consistent with temperature gradient observations between $-0.0046^{\circ} \mathrm{C} \mathrm{m}^{-1}$ (monsoon) and $-0.0064^{\circ} \mathrm{C} \mathrm{m}^{-1}$ (pre-monsoon) in a nearby Himalayan catchment (Immerzeel et al., 2014b). The standard deviation in calculated $\gamma_{T}$ is lowest during the monsoon and greatest in the winter.

At all four EVK2CNR stations, daily temperatures estimated from APHRODITE vertical gradients are greater than observed, with mean daily differences ranging from -1 to $+8^{\circ} \mathrm{C}$ (Fig. 4). Micro-meteorological conditions may contribute to the larger biases observed at Pyramid (winter) and Pheriche (summer). During the summer monsoon pe- 
riod (mid-June to mid-September), the mean difference for all stations is approximately $5^{\circ} \mathrm{C}$. We develop a bias correction for the day of year (DOY) based on the mean temperature bias from the four stations, which ranges from 3.22 to $6.00^{\circ} \mathrm{C}$. The largest bias coincides with the approximate onset of the summer monsoon (DOY 150, or 31 May). A possible mechanism for this is the pre-monsoon increase in humidity at lower elevations, which would be well-represented in the gridded APHRODITE data but not at the higher elevation EVK2CNR stations. The increased humidity would result in a less negative derived temperature gradient, and thus greater errors at the high-elevation stations. The variability in calculated temperature gradients is sharply reduced at onset of the monsoon, which supports this hypothesis. Biascorrected estimates of daily temperature (Fig. 9) have root mean squared errors (RMSE) of 1.21 to $2.07^{\circ} \mathrm{C}$ and mean bias errors (MBE) of -0.87 to $0.63^{\circ} \mathrm{C}$.

Based on the calculated daily temperature gradients, intercepts, and the bias correction, we estimate the height of the $0^{\circ} \mathrm{C}$ isotherm $\left(Z_{T=0}\right)$ for the period $1961-2007$ to examine melt potential and snow-line elevations. Mean monthly values of $Z_{T=0}$ range from $3200 \mathrm{~m}$ (January) to $5800 \mathrm{~m}$ (July), though it can reach elevations of over $6500 \mathrm{~m}$ on occasion. This corresponds to meteorological observations from Langtang Valley, Nepal (Shea et al., 2015), and from the Khumbu Valley (http://www.the-cryosphere-discuss.net/ 7/C1879/2013/tcd-7-C1879-2013.pdf).

Daily precipitation-elevation functions (Fig. 5) exhibit strong decreases in precipitation above $4000 \mathrm{~m}$, particularly in the monsoon and pre-monsoon periods. Absolute precipitation totals are greatest during the monsoon period, but large precipitation events can still occur in the post-monsoon period (October-November). As often observed in highelevation environments, daily precipitation totals observed at the EVK2CNR stations are not well captured by the downscaling process (Fig. 6). This is likely due to the difficulties in estimating precipitation in complex terrain (Immerzeel et al., 2012; Pellicciotti et al., 2012) and to errors in the precipitation measurements. For daily liquid precipitation $\left(T>0{ }^{\circ} \mathrm{C}\right)$, RMSEs range between 2.05 and $8.21 \mathrm{~mm}$, while MBEs range from -0.85 to $1.77 \mathrm{~mm}$. However, accumulated precipitation totals (Fig. 6) and mean monthly precipitation values show greater coherence, which lends some support for the downscaling approach used. At Pyramid (5035 m), the highest station with precipitation observations, the fit between cumulative predicted and observed precipitation is quite close. However, at Pheriche $(4260 \mathrm{~m})$, predicted precipitation is nearly double that observed over the period of record, which suggests that further refinements to the precipitation downscaling method are needed.

\subsection{Model results and validation}

For the calibration runs, we report here volume and area values averaged between 1 November and 31 January. Reported uncertainties are the standard deviation in modelled values from the 20 simulations. Modelled ice volumes from the 20 calibration runs (Fig. 10) decrease from $41.0 \mathrm{~km}^{3}$ in 1961 to between 31.6 and $37.1 \mathrm{~km}^{3}$ in 2007 , with a 20 -member mean of $34.5 \pm 1.5 \mathrm{~km}^{3}$ at the end of the simulation period. The ensemble mean modelled glacierized area in the calibration runs decreases from $499 \mathrm{~km}^{2}$ to $392 \pm 11 \mathrm{~km}^{2}$, with a final range of 374 to $397 \mathrm{~km}^{2}$.

Parameters for the calibrated model were chosen from Run 5, which had the lowest additive score of the 20 parameter sets (Table 4). Run 5 generates glacier volume and area totals that are lower but within 1 standard deviation of the model mean (Fig. 10). The selected parameter set contains degree-day factors (Table 2) that are all slightly higher than those observed by Azam et al. (2014) at Chhota Shigri Glacier but are similar to values obtained for snow and ice by Singh et al. (2000) at Dokriani Glacier, Garhwal Himalaya. The value of the material roughness coefficient in the selected parameter set lies between the values used previously in Baltoro (Pakistan) and Langtang (Nepal, Fig. 1) catchments (Immerzeel et al., 2013, Supplementary Information).

Spatially distributed output from the calibrated model (Run 5), 1961-2007, is summarized in Fig. 11. Mean annual ablation (Fig. 11a) ranges from 0 to $4.00 \mathrm{~m}$ w.e. $\mathrm{yr}^{-1}$, though most modelled values are less than $1.80 \mathrm{~m}$ w.e. $\mathrm{yr}^{-1}$. Debris-covered termini, despite having lower degree-day factors, are nevertheless subjected to large melt rates due to their relatively low elevation and consequently higher temperatures. Our model generates maximum melt rates at the transition between debris-covered and clean glacier ice, at elevations of approximately $5000 \mathrm{~m}$ (Fig. 2). This is consistent with geodetic observations of mass change in the catchment (e.g. Bolch et al., 2008b). Maximum mean annual snowfall (Fig. 11b) amounts of up to $0.50 \mathrm{mw}$ w.e. $\mathrm{yr}^{-1}$ are observed at $6268 \mathrm{~m}$ (the calibrated value of $Z_{C}$, Table 2), but due to the precipitation scaling function (Eq. 2) the highest peaks receive zero snowfall amounts. The calibrated height of $Z_{\mathrm{C}}$ $(6268 \mathrm{~m})$ is similar to the elevation of maximum snowfall (between 6200 and $6300 \mathrm{~m}$ ) estimated for the Annapurna range in mid-Nepal (Fig. 1; Harper and Humphrey, 2003).

Modelled glacier velocities during the calibration period are less than $10 \mathrm{~m} \mathrm{yr}^{-1}$ over debris-covered glacier termini and between 30 and $100 \mathrm{~m} \mathrm{yr}^{-1}$ between the accumulation and ablation zones. While there are differences in both the spatial pattern and magnitude of modelled and observed velocities (e.g. Quincey et al., 2009), we feel that our simplification of glacier dynamics is unavoidable in the current study, and the development of higher-order physically based models will lead to improved representations of glacier flow.

\subsubsection{Mass balance}

Over the entire domain, modelled mean annual mass balances $\left(b_{\mathrm{a}}\right.$; Fig. 11c) range from -4.6 to $+3.0 \mathrm{~m}$ w.e. $\mathrm{yr}^{-1}$, 

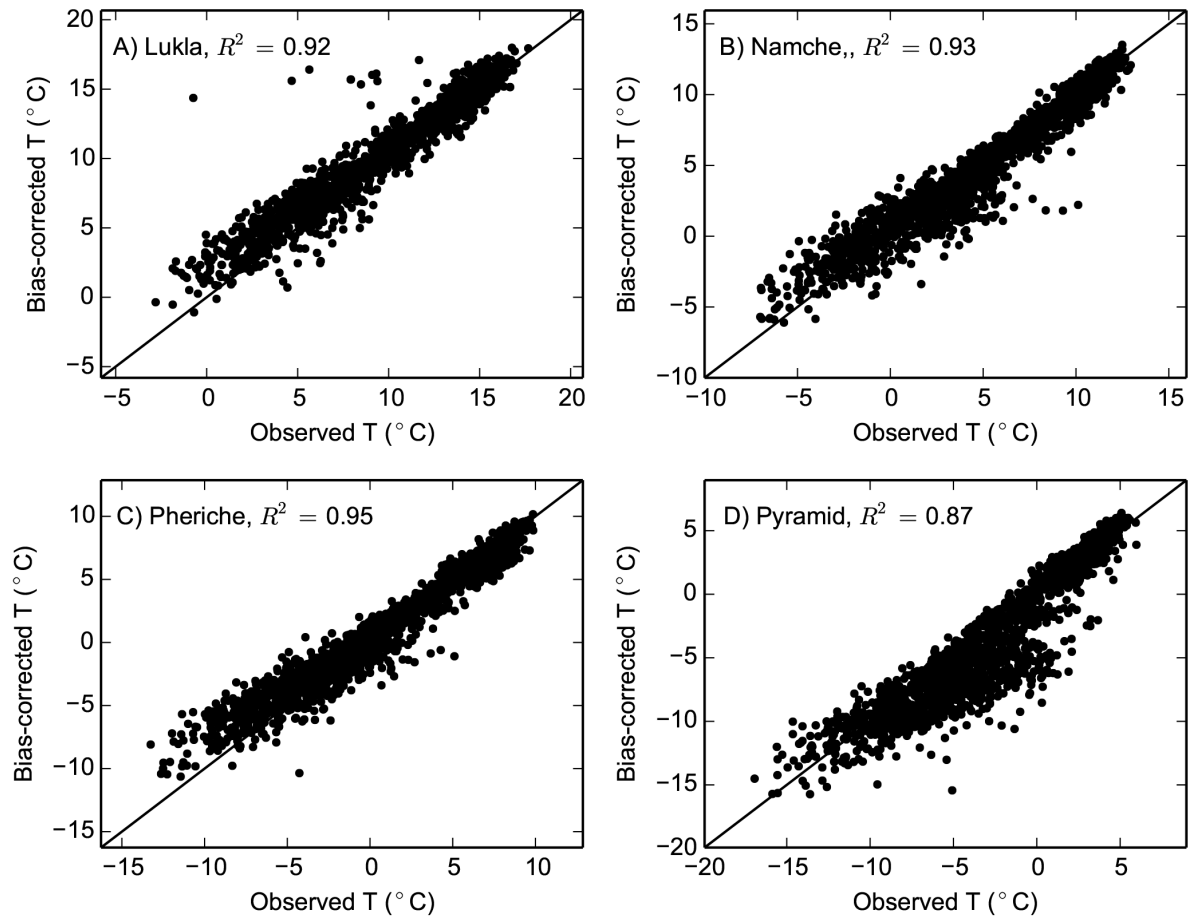

Figure 9. Mean daily temperatures observed at EVK2CNR sites (2003-2007) versus bias-corrected temperatures estimated from APHRODITE temperature fields.

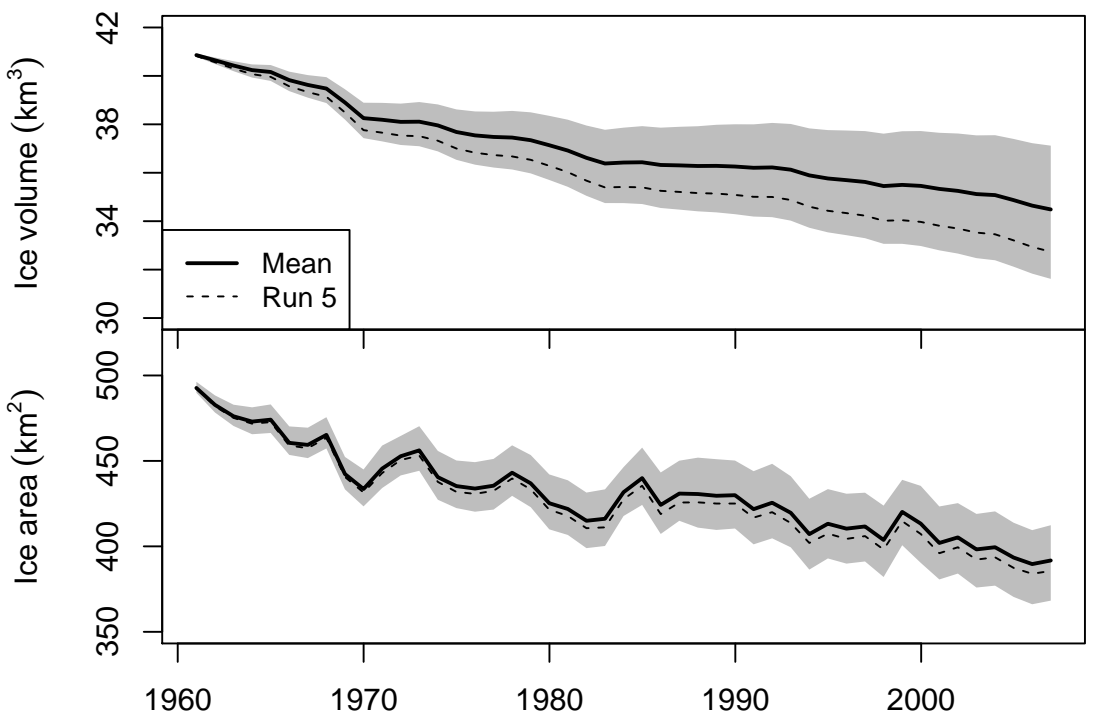

Figure 10. Top panel: modelled mean (1 November-31 January) ice volumes from the 20 calibration runs, 1961-2007, with multi-model mean (black line), minimum and maximum modelled volumes (shaded area), and results from Run 5 (dashed line). Bottom panel: as above but for modelled glacier areas from the 20 calibration runs.

with the majority of values falling between -1.4 and $+0.1 \mathrm{~m}$ w.e. $\mathrm{yr}^{-1}$. The spatial patterns of modelled annual mass balance are consistent with the geodetic estimates of mass change between 2000 and 2010, and our modelled basin-wide mass balance of $-0.33 \mathrm{~m}$ w.e. $\mathrm{yr}^{-1}$ is only slightly more negative than the basin-wide estimates of
$-0.26 \pm 0.13 \mathrm{~m}$ w.e. $\mathrm{yr}^{-1}$ given by Gardelle et al. (2013) and $-0.27 \pm 0.08 \mathrm{~m}$ w.e. $\mathrm{yr}^{-1}$ given by Bolch et al. (2011) for the Khumbu region only.

The overall Dudh Koshi mass balance gradient (Run 5), calculated from median modelled $b_{\mathrm{a}}$ for all glacierized cells in $100 \mathrm{~m}$ intervals between 4850 and $5650 \mathrm{~m}$, is equiva- 

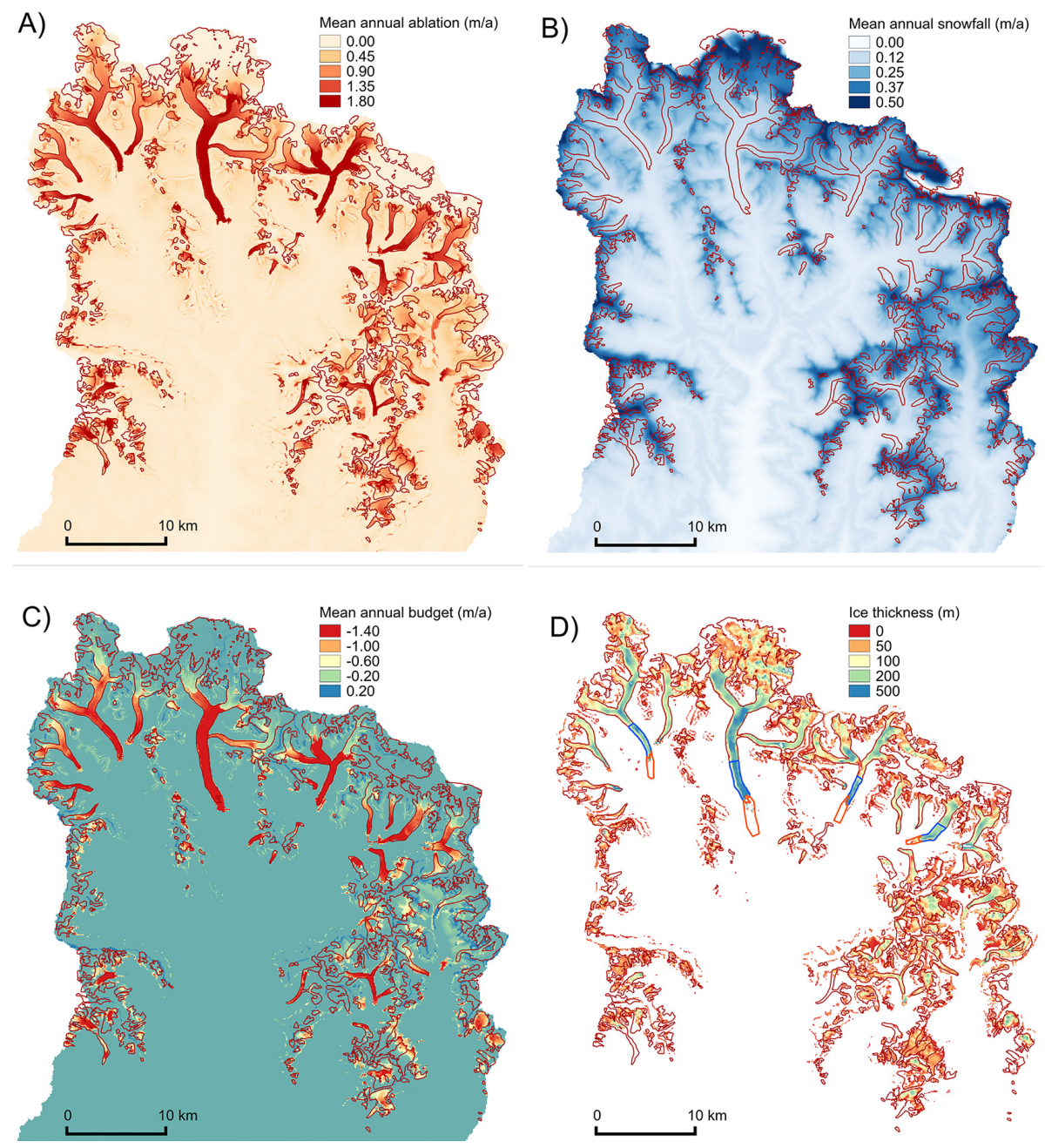

Figure 11. Results from the calibrated model run, 1961-2007. (a) Mean annual ablation, (b) mean annual snowfall, (c) mean annual mass budget, and (d) final ice thickness. Extents of glacierized and non-glacierized calibration regions are shown in (d).

lent to $0.27 \mathrm{~m}$ w.e. $(100 \mathrm{~m})^{-1}$ (Fig. 12). The range of mass balance gradients for the other 19 parameter sets ranges from 0.10 to $0.34 \mathrm{~m}$ w.e. $(100 \mathrm{~m})^{-1}$. The mass balance gradient from Run 5 gives a basin-wide ELA at approximately $5500 \mathrm{~m}$, which agrees with previously published estimates (Williams, 1983; Asahi, 2010; Wagnon et al., 2013). Mass balance gradients (Run 5) at Mera and Naulek glaciers are approximately 0.40 and $0.68 \mathrm{~m}$ w.e. $(100 \mathrm{~m})^{-1}$, respectively, between 5350 and $5600 \mathrm{~m}$. These values compare well with the gradients of 0.48 and $0.85 \mathrm{~m}$ w.e $(100 \mathrm{~m})^{-1}$ observed over the same elevation range at Mera and Naulek between 2007 and 2012 (Wagnon et al., 2013). Calculated mass balance gradients from the different parameter sets range from 0.31 to $0.35 \mathrm{~m}$ w.e. $(100 \mathrm{~m})^{-1}$ at Mera Glacier and from 0.46 to $0.72 \mathrm{~m}$ w.e. $(100 \mathrm{~m})^{-1}$ at Naulek Glacier (Fig. 12).

Modelled annual mass balances $\left(B_{\mathrm{a}}\right)$ at Mera Glacier (1961-2007) range between -1.45 and +0.11 mw.e. (Fig. 13), with low variability amongst the different pa- rameter sets. Surface mass balance observations at the same site from 2007 to 2012 range between -0.67 and $+0.46 \mathrm{~m}$ w.e. (Wagnon et al., 2013). As model and observation periods do not overlap, direct comparisons between modelled and observed mass balances are not possible. However, the mean mass balance observed at Mera Glacier between 2007 and 2012 is $-0.08 \mathrm{~m}$ w.e., whereas the mean modelled mass balance between 2000 and 2006 is $-0.16 \mathrm{~m}$ w.e. We note that our reconstructed mass balance series at Mera Glacier shows strong similarities to the reconstructed mass balance at Chhota Shigri Glacier (Azam et al., 2014), with balanced conditions in the late 1980s and early 1990s. Standard deviations of observed and modelled mass balance are 0.51 and $0.29 \mathrm{~m}$ w.e., respectively, and the greater variability in observed $b_{\mathrm{a}}$ is likely linked to the short observation period (5 years) and to enhanced local variability which cannot be captured with downscaled climate fields. The mass balance model, although it may underestimate the 

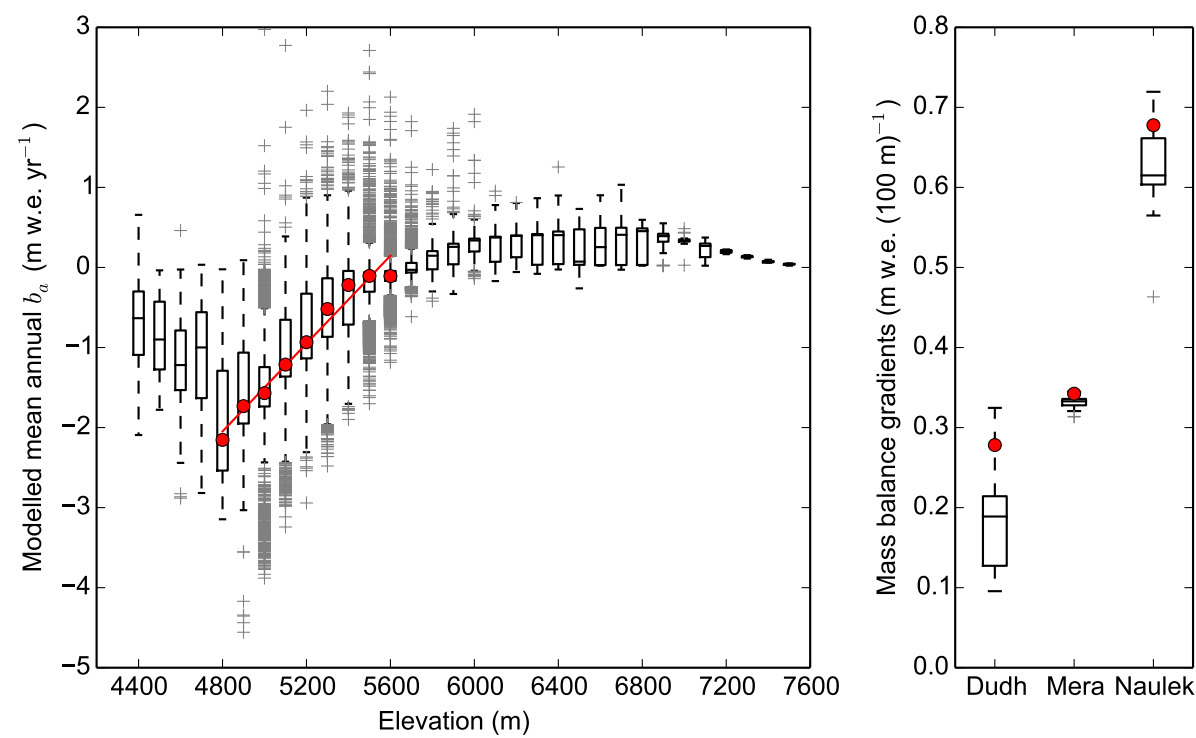

Figure 12. Left: boxplots of modelled mean annual mass balance ( $\mathrm{m}$ w.e. $\mathrm{yr}^{-1}$ ) calculated for $100 \mathrm{~m}$ intervals (1961-2007) for the entire Dudh Koshi basin. Calculated mass balance gradient of $0.27 \mathrm{~m}$ w.e. $(100 \mathrm{~m})^{-1}$ between 4850 and $5650 \mathrm{~m}$ is shown in red. Right: boxplots of mass balance gradients calculated for all 20 calibration model runs for the entire Dudh Koshi (between 4850 and $5650 \mathrm{~m}$ ), Mera Glacier (between 5350 and $5600 \mathrm{~m}$ ), and Naulek Glacier (between 5350 and $5600 \mathrm{~m}$ ). The gradients calculated for Run 5 are shown in red.

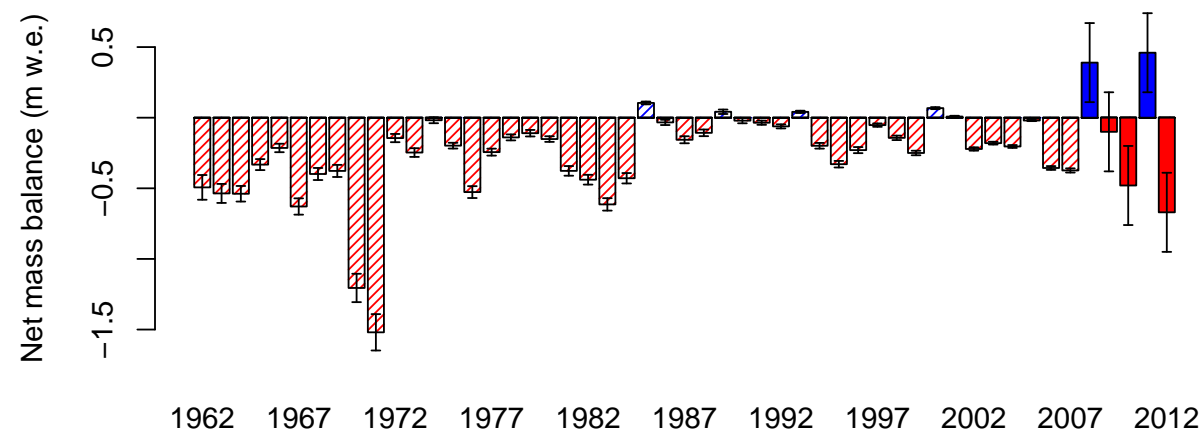

Figure 13. Modelled (dashed) and observed (solid) annual net mass balance at Mera Glacier, 1961-2007. Error bars for the modelled mass balances derived from the standard deviation of the annual mass balances extracted from 20 calibration runs, and error bars for the observed mass balances are from Wagnon et al. (2013).

inter-annual variability, is able to simulate a surface mass balance that is in a plausible and realistic range.

\subsubsection{Modelled and observed glacier thickness}

At the end of the calibrated run (1961-2007), modelled ice thicknesses range between 0 and $620 \mathrm{~m}$, though $98 \%$ of these are less than $205 \mathrm{~m}$ (Fig. 11d). Similar ice thicknesses have been estimated for the large debris-covered Gangotri Glacier, Indian Himalaya, using slope, surface velocities, and simple flow laws (Gantayat et al., 2014). Due to the model formulation, low-angle slopes on glacier termini may result in unrealistic estimates of ice depth, and a minimum surface slope of $1.5^{\circ}$ is prescribed in the model. Radio-echo surveys in 1999 indicated that centerline ice thicknesses on the Khumbu Glacier decreased from approximately $400 \mathrm{~m}$ at Everest Base
Camp to less than $100 \mathrm{~m}$ near the terminus (Gades et al., 2000). Our model accurately captures this decrease in the upper portions but overestimates ice thickness in the relatively flat terminus. Recent observations of ice thickness obtained from ground penetrating radar (GPR) surveys in the basin are examined in detail below.

Estimates of glacier thickness extracted from the calibrated model and are compared with depth profiles found with GPR surveys conducted at Mera Glacier (Wagnon et al., 2013) and Changri Nup Glacier (C. Vincent, unpublished data). To facilitate the comparison, we obtained surface elevations and bedrock depths from the GPR surveys, and we matched these to the modelled ice thicknesses of the corresponding pixels (Fig. 14). At the lower elevation profile on Mera Glacier $(5350 \mathrm{~m})$, the shape of the bedrock profile is 

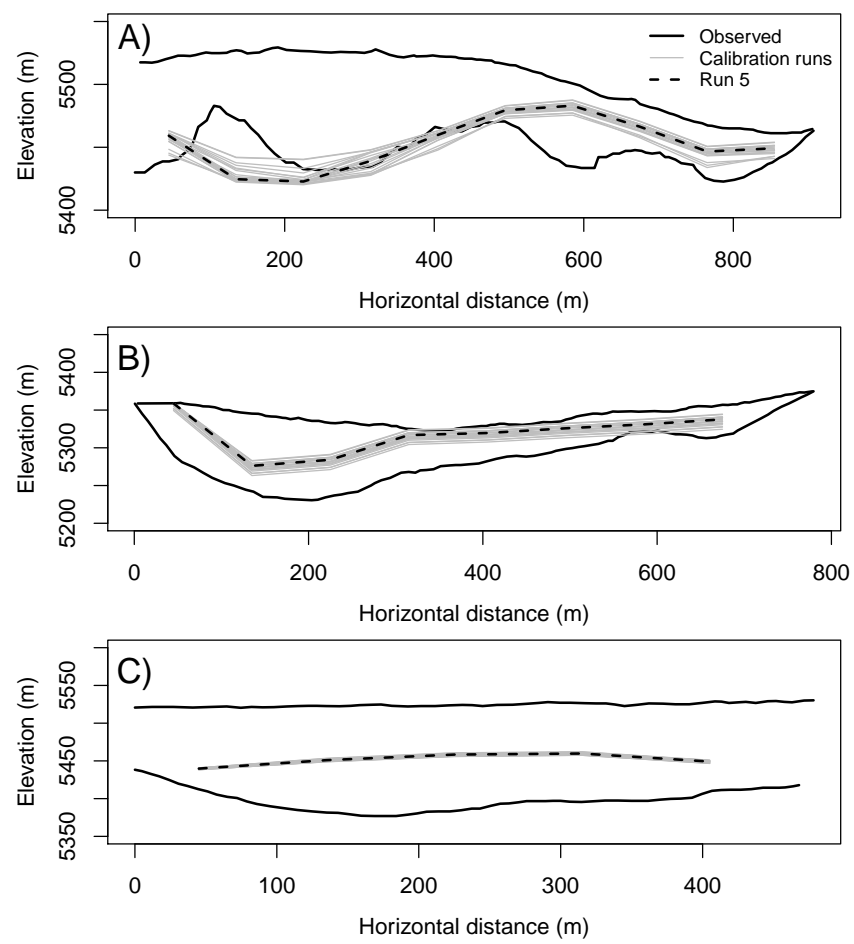

Figure 14. Glacier depths estimated from transverse ground-based GPR surveys and the mass balance and redistribution model, for (a) profile at $5350 \mathrm{~m}$ on Mera Glacier, (b) profile at $5520 \mathrm{~m}$ on Mera Glacier, and (c) profile at Changri Nup Glacier (Fig. 1). Ice depth estimates for all 20 calibration runs are given in grey, and the results for Run 5 are shown as a dashed black line.

similar to the model, but ice thicknesses are approximately half what is observed or less. This may be due in part to the surface slope extracted from the DEM, which controls the modelled ice thickness. The transect at $5350 \mathrm{~m}$ was collected in a flat section between two steeper slopes, which would likely be mapped as a steep slope in the DEM. For the profile at $5520 \mathrm{~m}$ both the shape and the depths of the bedrock profile are generally well-captured by the model. At the Changri Nup cross section, which lies on a relatively flat section of the main glacier body, modelled ice depths are approximately two-thirds of the observed. Modelled ice depths do not appear to be highly sensitive to the range of model parameters used in the 20 calibration runs, though variability is higher for Mera Glacier than for Changri Nup.

\subsubsection{Modelled and observed glacier extents and shrinkage}

Modelled historical changes in glacier area (Fig. 10) exhibit greater variability than modelled ice volumes. This is largely due to the sensitivity of the modelled glacier area to large snowfall events, as snowfall amounts greater than the $0.2 \mathrm{~m}$ w.e. threshold are classified as glacier. To compare

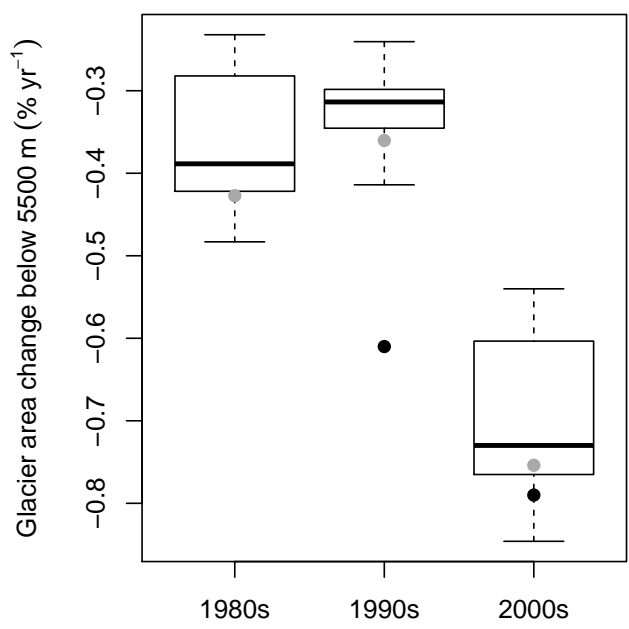

Figure 15. Rates of historical glacier area change below $5500 \mathrm{~m}$ $\left(\% \mathrm{yr}^{-1}\right)$ from the 20 model runs. Remotely sensed rates of glacier area change and Run 5 results are shown as black and grey points, respectively. The 1980's inventory contained inaccuracies related to the resolution of the imagery and the misclassification of snow as glacier ice, and an observed rate of change from 1980 to 1990 is not included here.

modelled and observed extents we use the mean extent at the end of the ablation season (1 November-31 January).

Using semi-automated classifications of Landsat imagery, glacier extents in the Dudh Koshi basin were constructed for 1990, 2000, and 2010 (ICIMOD, 2011; Bajracharya et al., 2014a, available at rds.icimod.org). As the glacier change signal is greatest at lower elevations, and errors in glacier delineation due to persistent snow cover are possible at higher elevations, we consider the change in glacier area below $5500 \mathrm{~m}$, which roughly equals the equilibrium line altitude in the catchment.

Below $5500 \mathrm{~m}$, the observed rate of glacier area change in the Dudh Koshi was $-0.61 \% \mathrm{yr}^{-1}$ between 1990 and 2000, and $-0.79 \% \mathrm{yr}^{-1}$ between 2000 and 2010 . For the 20 parameter sets, modelled rates of glacier area change below $5500 \mathrm{~m}$ (Fig. 15) vary between $-0.24 \%$ and $0.41 \% \mathrm{yr}^{-1}$ (1990-2000) and -0.54 and $-0.85 \% \mathrm{yr}^{-1}$ (2000-2007) for the 20 parameter sets. The calibrated run (Run 5) gives area change rates of -0.36 and $-0.75 \% \mathrm{yr}^{-1}$ for the $1990-2000$ and 2000-2007 periods, respectively. Both modelled and observed glacier change are of similar magnitudes, and both show a consistent trend of increasing area loss, which is corroborated by other studies in the region (Bolch et al., 2008b; Thakuri et al., 2014). Salerno et al. (2014) cite a weakened monsoon with reduced accumulation at all elevations as a main reason for the increased mass loss in recent years. Differences between modelled and observed rates of glacier shrinkage can be attributed to errors in the glacier inventory, e.g. geometric correction and interpretation errors, uncertainty in our estimates of initial ice volumes, and other model errors which are discussed below. 
Table 6. Mean $(\bar{x})$ and standard deviation $(\sigma)$ in percent modelled glacier volume change for RCP4.5 and RCP8.5 end-members at 2050 and 2100.

\begin{tabular}{ccccc}
\hline Scenario & $\bar{x}_{2050}$ & $\sigma_{2050}$ & $\bar{x}_{2100}$ & $\sigma_{2100}$ \\
\hline RCP4.5 & -39.3 & 16.8 & -83.7 & 11.2 \\
RCP8.5 & -52.4 & 14.5 & -94.7 & 4.2 \\
\hline
\end{tabular}

\subsection{Glacier sensitivity to future climate change}

Decadal temperature and precipitation anomalies extracted from members of the CMIP5 ensemble that capture a range of climate scenarios (Table 5) are applied to the historical APHRODITE $T$ and $P$ fields. The calibrated glacier mass and redistribution model is then used to explore the sensitivity of modelled glaciers to future climate change in the Dudh Koshi basin. From initial glacier volumes and extents (Eq. 8), the mean projected changes in total ice volume at 2050 are -39.3 and $-52.4 \%$ for RCP4.5 and RCP8.5 emissions scenarios, respectively (Table 6). The minimum projected volume change at 2050 is $-26 \%$ (cold/wet), and the maximum is $-70 \%$ (warm/dry). At 2100 the projected mean total volume loss is estimated at $-83.7 \%$ for RCP4.5 scenarios, and $-94.7 \%$ for RCP8.5, with a range between -70 and $-99 \%$. Radić et al. (2014) and Marzeion et al. (2012), respectively, estimate mean glacier volume changes in south-east Asia of -50 and $-60 \%$ for RCP4.5 scenarios and -75 and $-70 \%$ for RCP8.5 by 2100 . In all scenarios presented here, the rate of ice loss decreases towards the end of the simulation period (Fig. 16), which indicates a shift towards equilibrium mass balance conditions.

Increased precipitation may slow the rate of future mass loss, but it is not sufficient to offset the increases in glacier melt due to increased temperatures. Changes in the timing and magnitude of monsoon precipitation may thus be less important than previously believed (Mölg et al., 2012; Bolch et al., 2012). The main difference between the RCP4.5 and RCP8.5 scenarios is the magnitude of the temperature increase, which leads to greater losses of ice volume in the RCP8.5 scenarios. This is due in part to the increased melt but also to the expansion of the ablation area and the change in precipitation phase from solid to liquid. Based on the daily temperature gradients and projected monthly temperature increases, the elevation of the $0{ }^{\circ} \mathrm{C}$ isotherm may increase by 800 to $1200 \mathrm{~m}$ by 2100 . A potential snow-line elevation of $7000 \mathrm{~m}$ in August would expose $90 \%$ of the current glacierized area to melt and severely restrict snow accumulation during the monsoon.

With a distributed model we can examine the possible impact of future climate change on Everest-region glacier area and thickness with respect to elevation. The patterns of decreases in ice area (Fig. 17) and ice thickness (Fig. 18) with elevation illustrate the combined effects of increased melt rates due to warmer temperatures and the insulating effect of debris cover. The greatest losses in glacier area, both relative and absolute, are expected at elevations close to the current ELA (approx. $5500 \mathrm{~m}$ ), where the greatest amount of debris-free ice area currently exists. At lower elevations, where glaciers are exclusively debris-covered (Fig. 2), modelled glacier thicknesses are greater (Fig. 11), melt rates are lower, and modelled changes in glacier area and volume will be less than those near the ELA.

Wet and cool scenarios for both the RCP4.5 and RCP8.5 scenarios show the possible survival of debris-covered glaciers between 4000 and $4500 \mathrm{~m}$, albeit with greatly reduced thicknesses (Fig. 18). In both warm and dry scenarios, glaciers below $5500 \mathrm{~m}$ could be eliminated, and in the RCP8.5 scenario, glacier thicknesses between 6000 and $6500 \mathrm{~m}$ could experience reductions by the year 2100. According to these scenarios, no changes are expected in the glacier volumes at elevations above $7000 \mathrm{~m}$.

Our most conservative realization (RCP4.5 dry/cold, $T+$ $1.5^{\circ} \mathrm{C}, P+12.3 \%$ by 2050$)$ shows virtually no change in glaciers above $6000 \mathrm{~m}$ (Fig. 17b). However, glacierized area near the current ELA $(5500 \mathrm{~m})$ may see declines of up to $80 \%$, and thinning will occur below $5750 \mathrm{~m}$ (Fig. 18). Debris-covered termini may see area reductions of $40 \%$ by 2100. The RCP8.5 warm/dry scenario $\left(+3.1^{\circ} \mathrm{C},-2.8 \% P\right.$ by 2050$)$ is the worst-case realization, in which glaciers below $6500 \mathrm{~m}$ are essentially eliminated by 2100 (Fig. 17c).

\section{Discussion}

Through a multi-parameter calibration and validation with independent data sets, we model the mass balance and mass redistribution of glaciers in the Dudh Koshi basin over the period 1961-2007. Temperature and precipitation changes specified from end-members of the CMIP5 ensemble are applied to historical climate fields to examine the sensitivity of glaciers in the region to future climate change. Expected increases in temperature will result in sustained mass losses that are only partially offset by increases in precipitation. We can identify three main sources of uncertainty in our approach: parametric, structural, and climate inputs. These are discussed below. Although considerable progress is made in this study by the systematic integration of field-based observations into our modelling approach, there are still a number of key challenges to be addressed in the future.

\subsection{Structural uncertainty}

The glacier mass balance and redistribution model used in this study has precedents in other studies (Immerzeel et al., 2012, 2013) and has been calibrated here with observational data. While the model is a simplification of complex ice flow and dynamical processes, it is an important tool that can be used to explore the sensitivity of glaciers in the region 


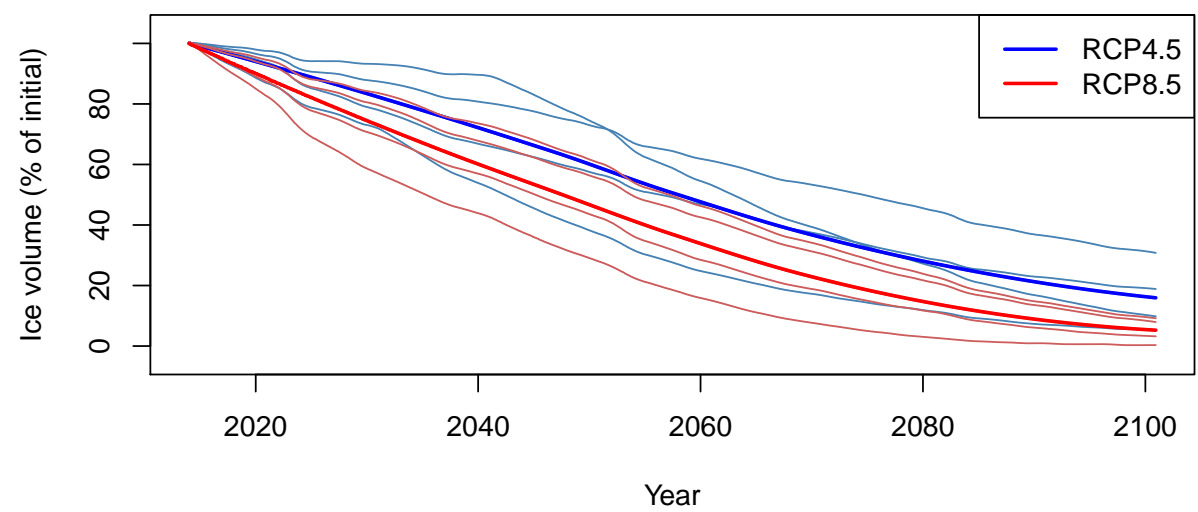

Figure 16. Sensitivity of modelled glacier volumes to decadal $T$ and $P$ anomalies from four RCP4.5 (blue) and four RCP8.5 (red) ensemble members (see Table 5 for details). Realizations are given as thin lines, and ensemble means are thick lines. All realizations are smoothed with a loess filter $(\operatorname{span}=0.05)$ to minimize interannual variations.
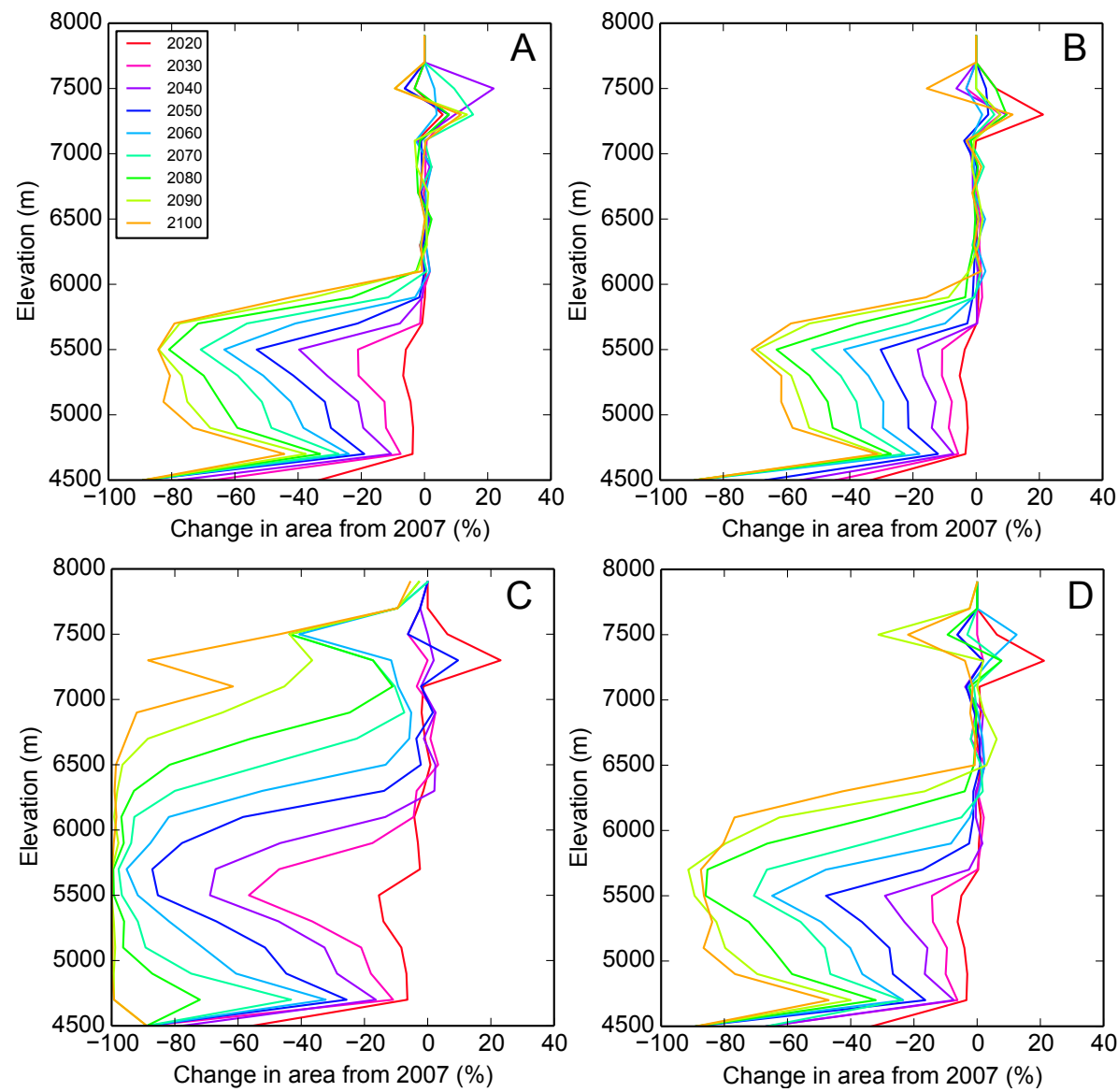

Figure 17. Change in glacier area versus elevation for (a) the dry/warm RCP4.5 scenario, (b) the wet/cool RCP4.5 scenario, (c) the dry/warm RCP8.5 scenario, and (d) the wet/cool RCP8.5 scenario.

to future climate change. Given the forcings $\left(-1.2^{\circ} \mathrm{C}\right.$ over 47 years) and parameter set (uncalibrated) used in the initialization, and the lag in actual glacier geometry response to climate change, it is possible that there are additional uncertainties in our estimates of initial ice volumes.
Our assumption of stationary debris cover may also be incorrect in the long-term, as glacier wastage typically leads to increased debris concentrations and the development of a debris cover. However, the median glacier slope above $5500 \mathrm{~m}$ is greater than $20^{\circ}$ (Fig. 7), and the development of debris 

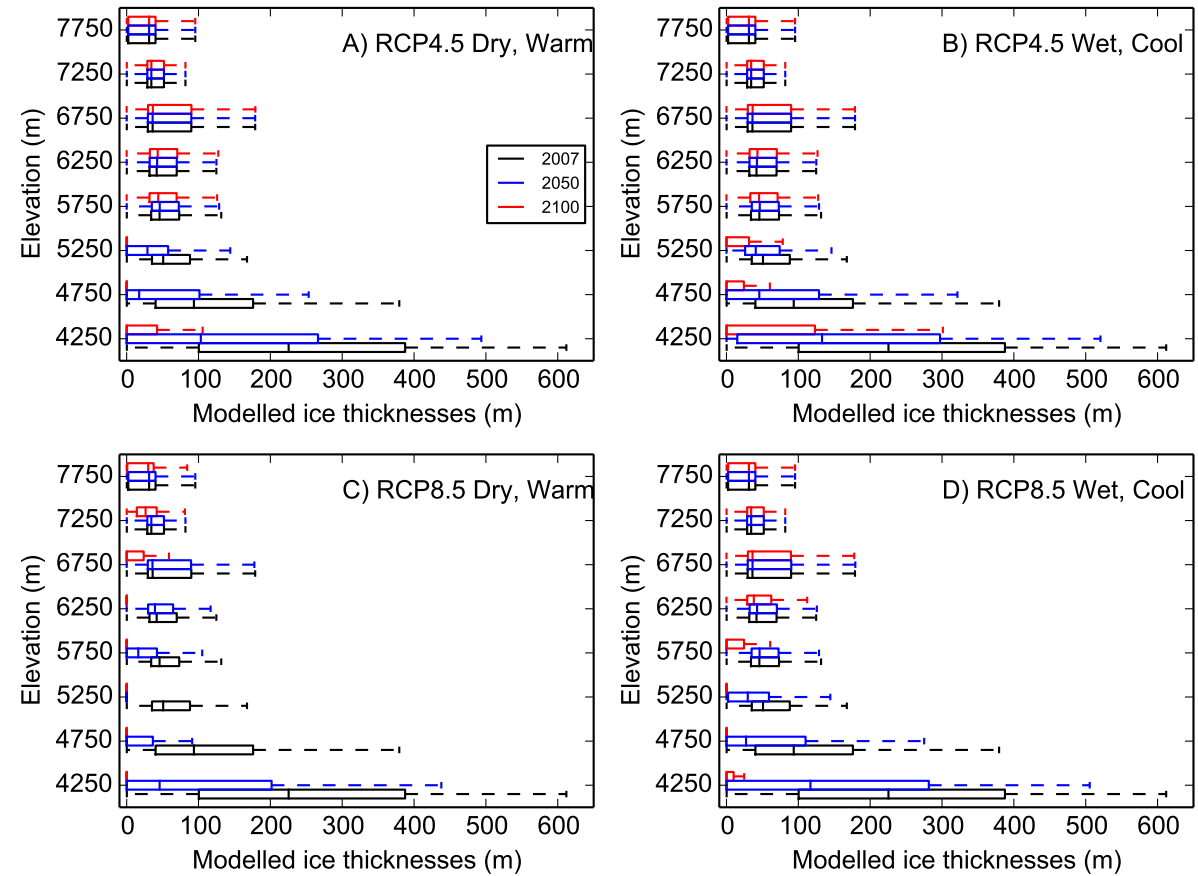

Figure 18. Distribution of modelled ice thicknesses by elevation band, for 2007 (initialization), 2050, and 2100. (a) Dry/warm RCMP4.5 scenario, (b), wet/cool RCP4.5 scenario, (c) dry/warm RCP8.5 scenario, and (d) wet/cool RCP8.5 scenario.

cover on such slopes is unlikely (cf. Fig. 3b, Scherler et al., 2011a) as de-glaciation proceeds. Until higher-order models of glacier dynamics (e.g. Adhikari and Huybrechts, 2009; Clarke et al., 2015) are sufficiently advanced and explicitly include the effects of debris cover, and the additional input data (bedrock topography, ice temperatures) are wellconstrained, simple modelling approaches will still be required for basin-scale analyses of glacier change scenarios.

\subsection{Parametric uncertainty}

Our calibration approach relies on 20 sets of six different parameters with values taken randomly from pre-assigned initial values and ranges (Table 3). Model results from the 20 parameter sets (Figs. 12, 13, 14) suggest that the parametric uncertainty is well-constrained. The selected set of calibrated parameters is similar to those used in other regions (Immerzeel et al., 2012, 2013), but a much larger and more computationally expensive Monte Carlo-type simulation must be undertaken to reduce the parametric uncertainty. Additional calibration data sets would also be beneficial, and these could include a greater number of ice depth measurements from debris-covered and clean-ice glaciers, remotely sensed snow cover, and glacier mass balance.

\subsection{Input climate data uncertainty}

The lack of high-elevation temperature and precipitation data to force the mass balance model is one of the key challenges that nearly all Himalayan modelling studies face. In this study, we derive temperature gradients and precipitationelevation functions from the $0.25^{\circ}$ gridded APHRODITE data, which in turn is based primarily on low-elevation stations. The downscaling approach is then tested with semiindependent station data from the EVK2CNR network of stations in the Dudh Koshi basin. While temperatures can be skillfully modelled after applying a bias correction based on the day of year, our ability to predict precipitation ranges from very good (at Pyramid) to very poor (at Pheriche). Difficulty in quantifying precipitation and precipitation gradients in high-mountain areas is likely one of the largest sources of uncertainty in mountain hydrology (Immerzeel et al., 2012; Nepal et al., 2013). Further investigations into high-elevation precipitation gradients, through field studies, remote sensing derivatives, and/or the use of high-resolution numerical weather models, will help to increase our understanding of glacier nourishment in the region. An analysis of the sensitivity of modelled glacier change to the rain/snow threshold temperature is also recommended.

\subsection{Response times}

Glaciers in the region are highly sensitive to temperature changes. Precipitation increases of $15 \%$ (mostly during the monsoon season) will be unable to counter the loss of glacier mass due to increased melt rates. For intense warming scenarios, our ensemble mean volume change is more negative than regional estimates given by both Marzeion et al. (2012) and Radić et al. (2014). The potential loss of lower-elevation 
glaciers in the study area raises the question of glacier response times. The actual response times of glaciers in the region can be approximated from modelled thicknesses and mass balance rates near the glacier terminus, following the methods of Jóhannesson et al. (1989):

$$
\tau=\frac{-H^{\prime}}{\dot{b}_{\mathrm{a}}}
$$

where $H^{\prime}$ is a representative glacier thickness and $\dot{b}_{\mathrm{a}}\left(\dot{b}_{\mathrm{a}}>0\right)$ is the mean annual mass balance near the terminus. Given our modelled ice thicknesses and mean annual mass balances at the termini of glaciers throughout the catchment, Eq. (10) suggests that the smaller glaciers in the southern portions of the basin have total glacier response times on the order of 20-50 years, while the large debris-covered glaciers have response times of 200-500 years. These first-order estimates reflect the time it takes the glaciers to reach a new equilibrium state in response to a step change in climate (Cogley et al., 2011) and are in agreement with the modelled persistence of debris-covered termini and loss of smaller, lowelevation glaciers.

Our scenarios suggest that future reductions in glacier area will occur mainly in clean ice regions between accumulation areas and debris-covered termini. We anticipate that the hypsometric distribution of ice will become bi-modal as glacier mass loss proceeds: debris-covered tongues will continue to exist (in reduced states) at low elevations but will become separated from their high-elevation accumulation zones (Kääb, 2005). Current examples of this type of glacier change can be found at Chorabari Glacier, Garhwal Himalaya (Dobhal et al., 2013), and at Lirung Glacier (central Nepal) in nearby Langtang Valley (Immerzeel et al., 2014a), where glacier wastage above the debris-covered termini has left stagnant debris-covered ice below and small high-elevation ice masses above. Model scenarios from this study are thus consistent with field observations and suggest that this will become a familiar picture in the coming decades.

\section{Conclusions}

In the mountains of high Asia, changes in glacier volumes will impact the timing and magnitude of streamflows, particularly in the pre-monsoon period (Immerzeel et al., 2013). Our study advances the current understanding of Himalayan glacier evolution under climate change and examines the basin-scale evolution of glaciers in the Dudh Koshi basin of central Nepal using a distributed glacier mass balance and redistribution model. We constrain the glacier model parameters with observations where possible and calibrate against observations of net glacier mass change, velocities on debriscovered termini, and glacier extents. Our work represents a first-order estimate of future glacier change and is subject to considerable uncertainty from a number of sources.
Temperature and precipitation anomalies from endmember scenarios extracted from the CMIP5 RCP4.5 and RCP8.5 ensemble (Immerzeel et al., 2013) are applied to historical downscaled climate fields, and the model is used to explore the sensitivity of glaciers in the Dudh Koshi basin to future climate change. Modelled glacier sensitivity to temperature change is high, with large decreases in ice thicknesses and extents for even the most conservative climate change scenario. Future climate scenarios with increased precipitation and reduced warming result in decreased mass losses, though increases in precipitation are insufficient to offset the dramatic increase in mass loss through increased melting.

Glaciers in the region appear to be highly sensitive to changes in temperature, and projected increases in precipitation are insufficient to offset the increased glacier melt. While we have identified numerous sources of uncertainty in the model, the signal of future glacier change in the region is clear and compelling. Advancements in the representation of ice dynamics (Clarke et al., 2015) and understanding of highaltitude precipitation will result in improved catchment-scale estimates of glacier sensitivity to future climate change in high mountain Asia.

Acknowledgements. We gratefully acknowledge the Royal Norwegian Embassy at Kathmandu for funding the Cryosphere Monitoring Project at the ICIMOD and the contributions of Finu Shrestha and Sudan Maharajan to the glacier inventory work. This study was partially funded by the Netherlands Organization for Scientific Research through their VENI program and by the research for development (R4D) program of DFID, as well as core funds of ICIMOD contributed by the governments of Afghanistan, Australia, Austria, Bangladesh, Bhutan, China, India, Myanmar, Nepal, Norway, Pakistan, Switzerland, and the United Kingdom. Mera and Changri Nup glacier research was supported by the French Service d'Observation GLACIOCLIM and the French National Research Agency through ANR-09-CEP-005-01/PAPRIKA. This study was carried out within the framework of the Ev-K2-CNR Project in collaboration with the Nepal Academy of Science and Technology as foreseen by the Memorandum of Understanding between Nepal and Italy, and thanks to contributions from the Italian National Research Council, the Italian Ministry of Education, University and Research, and the Italian Ministry of Foreign Affairs. We also acknowledge the World Climate Research Programme's Working Group on Coupled Modelling, which is responsible for CMIP, and we thank the climate modelling groups for producing and making available their model outputs. The views and interpretations in this publication are those of the authors and are not necessarily attributable to ICIMOD. Ben Marzeion, Anne Rowan, Graham Cogley, Franco Salerno, and an anonymous reviewer provided invaluable comments and suggestions on previous versions of the manuscript.

Edited by: T. Bolch 


\section{References}

Adhikari, S. and Huybrechts, P.: Numerical modelling of historical front variations and the 21st-century evolution of glacier AX010, Nepal Himalaya, Ann. Glaciol., 50, 27-34, 2009.

Ageta, Y. and Higuchi, K.: Estimation of mass balance components of a summer-accumulation type glacier in the Nepal Himalaya, Geografiska Annaler Series A. Physical Geography, 66A, 249255, 1984.

Ageta, Y. and Kadota, T.: Predictions of changes of glacier mass balance in the Nepal Himalaya and Tibetan Plateau: a case study of air temperature increase for three glaciers, Ann. Glaciol., 16, 89-94, 1992.

Asahi, K.: Equilibrium-line altitudes of the present and Last Glacial Maximum in the eastern Nepal Himalayas and their implications for SW monsoon climate, Quaternary Int., 212, 26-34, doi:10.1016/j.quaint.2008.08.004, 2010.

Ashfaq, M., Shi, Y., Tung, W.-w., Trapp, R. J., Gao, X., Pal, J. S., and Diffenbaugh, N. S.: Suppression of south Asian summer monsoon precipitation in the 21 st century, Geophys. Res. Lett., 36, L01704, doi:10.1029/2008GL036500, 2009.

Azam, M. F., Wagnon, P., Vincent, C., Ramanathan, A., Linda, A., and Singh, V. B.: Reconstruction of the annual mass balance of Chhota Shigri glacier, Western Himalaya, India, since 1969, Ann. Glaciol., 55, 69-80, doi:10.3189/2014AoG66A104, 2014.

Bajracharya, S. R. and Mool, P.: Glaciers, glacial lakes and glacial lake outburst floods in the Mount Everest region, Nepal, Ann. Glaciol., 50, 81-86, doi:10.3189/172756410790595895, 2010.

Bajracharya, S., Maharjan, S., and Shrestha, F.: The status and decadal change of glaciers in Bhutan from the 1980s to 2010 based on satellite data, Ann. Glaciol., 55, 159-166, doi:10.3189/2014AoG66A125, 2014a.

Bajracharya, S., Maharjan, S., Shrestha, F., Bajracharya, O., and Baidya, S.: Glacier Status in Nepal and Decadal Change from 1980 to 2010 Based on Landsat Data, ICIMOD, available at: lib. icimod.org/record/29291, last access: 29 August 2014b.

Benn, D. I., Bolch, T., Hands, K., Gulley, J., Luckman, A., Nicholson, L. I., Quincey, D., Thompson, S., Toumi, R., and Wiseman, S.: Response of debris-covered glaciers in the Mount Everest region to recent warming, and implications for outburst flood hazards, Earth Sci. Rev., 114, 156-174, doi:10.1016/j.earscirev.2012.03.008, 2012.

Bernhardt, M. and Schulz, K.: SnowSlide: A simple routine for calculating gravitational snow transport, Geophys. Res. Lett., 37, L11502, doi:10.1029/2010GL043086, 2010.

Bolch, T., Buchroithner, M., Pieczonka, T., and Kunert, A.: Planimetric and volumetric glacier changes in the Khumbu Himal, Nepal, since 1962 using Corona, Landsat TM and ASTER data, J. Glaciol., 54, 592-600, doi:10.3189/002214308786570782, 2008a.

Bolch, T., Buchroithner, M. F., Peters, J., Baessler, M., and Bajracharya, S.: Identification of glacier motion and potentially dangerous glacial lakes in the Mt. Everest region/Nepal using spaceborne imagery, Nat. Hazards Earth Syst. Sci., 8, 13291340, doi:10.5194/nhess-8-1329-2008, 2008b.

Bolch, T., Pieczonka, T., and Benn, D. I.: Multi-decadal mass loss of glaciers in the Everest area (Nepal Himalaya) derived from stereo imagery, The Cryosphere, 5, 349-358, doi:10.5194/tc-5349-2011, 2011.
Bolch, T., Kulkarni, A., Kääb, A., Huggel, C., Paul, F., Cogley, J. G., Frey, H., Kargel, J. S., Fujita, K., Scheel, M., Bajracharya, S., and Stoffel, M.: The state and fate of Himalayan glaciers, Science, 336, 310-314, doi:10.1126/science.1215828, 2012.

Bookhagen, B. and Burbank, D.: Topography, relief, and TRMMderived rainfall variations along the Himalaya, Geophys. Res. Lett., 33, L08405, doi:10.1029/2006GL026037, 2006.

Chen, N. Sh., Hu, G. Sh., Deng, W., Khanal, N., Zhu, Y. H., and Han, D.: On the water hazards in the trans-boundary Kosi River basin, Nat. Hazards Earth Syst. Sci., 13, 795-808, doi:10.5194/nhess-13-795-2013, 2013.

Clarke, G. K. C., Jarosch, A. H., Anslow, F. S., Radic, V., and Menounos, B.: Projected deglaciation of western Canada in the twenty-first century, Nat. Geosci., doi:10.1038/ngeo2407, in press, 2015.

Cogley, J. G.: Present and future states of Himalaya and Karakoram glaciers, Ann. Glaciol., 52, 69-73, doi:10.3189/172756411799096277, 2011.

Cogley, J., Hock, R., Rasmussen, L., Arendt, A., Bauder, A., Braithwaite, R., Jansson, P., Kaser, G., Möller, M., Nicholson, L., and Zemp, M.: Glossary of glacier mass balance and related terms. IHP-VII Technical Documents in Hydrology No. 86, IACS Contribution No. 2, UNESCO-IHP, 126 pp., 2011.

Dimri, A. and Dash, S.: Wintertime climatic trends in the western Himalayas, Clim. Change, 111, 775-800, doi:10.1007/s10584011-0201-y, 2012.

Dimri, A., Yasunari, T., Wiltshire, A., Kumar, P., Mathison, C., Ridley, J., and Jacob, D.: Application of regional climate models to the Indian winter monsoon over the western Himalayas, Sci. Total Environ., 468, S36-S47, doi:10.1016/j.scitotenv.2013.01.040, 2013.

Dobhal, D., Mehta, M., and Srivastava, D.: Influence of debris cover on terminus retreat and mass changes of Chorabari Glacier, Garhwal region, central Himalaya, India, J. Glaciol., 59, 961971, doi:10.3189/2013JoG12J180, 2013.

Farr, T. G., Rosen, P. A., Caro, E., Crippen, R., Duren, R., Hensley, S., Kobrick, M., Paller, M., Rodriguez, E., Roth, L., Seal, D., Shaffer, S., Shimada, J., Umland, J., Werner, M., Oskin, M., Burbank, D., and Alsdorf, D.: The Shuttle Radar Topography Mission, Rev. Geophys., 45, RG2004, doi:10.1029/2005RG000183, 2007.

Fowler, A. C.: Weertman, Lliboutry and the development of sliding theory, J. Glaciol., 56, 965-972, doi:10.3189/002214311796406112, 2010.

Frey, H., Machguth, H., Huss, M., Huggel, C., Bajracharya, S., Bolch, T., Kulkarni, A., Linsbauer, A., Salzmann, N., and Stoffel, M.: Ice volume estimates for the Himalaya-Karakoram region: evaluating different methods, The Cryosphere Discuss., 7, 4813-4854, doi:10.5194/tcd-7-4813-2013, 2013.

Fujita, K. and Nuimura, T.: Spatially heterogeneous wastage of Himalayan glaciers, P. Natl. Acad. Sci., 108, 14011-14014, doi:10.1073/pnas.1106242108, 2011.

Gades, A., Conway, H., Nereson, N., Naito, N., and Kadota, T.: Radio echo-sounding through supraglacial debris on Lirung and Khumbu Glaciers, Nepal Himalayas, Proceedings of International Workshop on Debris Covered Glaciers, IAHS-AISH Publication, 264, 13-22, 2000.

Gantayat, P., Kulkarni, A., and Srinivasan, J.: Estimation of ice thickness using surface velocities and slope: case 
study at Gangotri Glacier, India, J. Glaciol., 60, 277-282, doi:10.3189/2014JoG13J078, 2014.

Gardelle, J., Berthier, E., and Arnaud, Y.: Slight mass gain of Karakoram glaciers in the early twenty-first century, Nat. Geosci., 5, 322-325, doi:10.1038/ngeo1450, 2012.

Gardelle, J., Berthier, E., Arnaud, Y., and Kääb, A.: Region-wide glacier mass balances over the Pamir-Karakoram-Himalaya during 1999-2011, The Cryosphere, 7, 1263-1286, doi:10.5194/tc7-1263-2013, 2013.

Gardner, A. S., Moholdt, G., Cogley, J. G., Wouters, B., Arendt, A. A., Wahr, J., Berthier, E., Hock, R., Pfeffer, W. T., Kaser, G., Ligtenberg, S. R. M., Bolch, T., Sharp, M. J., Hagen, J. O., Van Den Broeke, M., and Paul, F.: A reconciled estimate of glacier contributions to sea level rise: 2003 to 2009 , Science, $340,852-$ 857, doi:10.1126/science.1234532, 2013.

Gautam, M. R., Acharya, K., and Tuladhar, M. K.: Upward trend of streamflow and precipitation in a small, non-snow-fed, mountainous watershed in Nepal, J. Hydrol., 387, 304-311, 2010.

Glen, J. W.: The creep of polycrystalline ice, Royal Soc. London Proc. Series A, 228, 519-538, doi:10.1098/rspa.1955.0066, 1955.

Harper, J. T. and Humphrey, N. F.: High altitude Himalayan climate inferred from glacial ice flux, Geophys. Res. Lett., 30, 1764, doi:10.1029/2003GL017329, 2003.

Hewitt, K.: Tributary glacier surges: an exceptional concentration at Panmah Glacier, Karakoram Himalaya, J. Glaciol., 53, 181-188, doi:10.3189/172756507782202829, 2007.

Huss, M. and Farinotti, D.: Distributed ice thickness and volume of all glaciers around the globe, J. Geophys. Res.-Earth Surf., 117, F04010, doi:10.1029/2012JF002523, 2012.

ICIMOD: The status of glaciers in the Hindu Kush-Himalayan region, ICIMOD, available at: http://lib.icimod.org/record/ 9419/files/icimod-the_status_of_glaciers_in_the_hindu_ kush-himalayan_region\%5B1\%5D.pdf, 2011.

Immerzeel, W. W., van Beek, L. P. H., and Bierkens, M. F. P.: Climate change will affect the Asian water towers, Science, 328, 1382-1385, doi:10.1126/science.1183188, 2010.

Immerzeel, W., van Beek, L., Konz, M., Shrestha, A., and Bierkens, M.: Hydrological response to climate change in a glacierized catchment in the Himalayas, Clim. Change, 110, 721-736, doi:10.1007/s10584-011-0143-4, 2012.

Immerzeel, W., Pellicciotti, F., and Bierkens, M.: Rising river flows throughout the twenty-first century in two Himalayan glacierized watersheds, Nat. Geosci., 6, 742-745, doi:10.1038/ngeo1896, 2013.

Immerzeel, W., Kraaijenbrink, P., Shea, J., Shrestha, A., Pellicciotti, F., Bierkens, M., and de Jong, S.: High-resolution monitoring of Himalayan glacier dynamics using unmanned aerial vehicles, Remote Sens. Environ., 150, 93-103, 2014a.

Immerzeel, W. W., Petersen, L., Ragettli, S., and Pellicciotti, F.: The importance of observed gradients of air temperature and precipitation for modeling runoff from a glacierized watershed in the Nepalese Himalayas, Water Resour. Res., 50, 2212-2226, doi:10.1002/2013WR014506, 2014b.

Inoue, J.: Mass budget of Khumbu Glacier: glaciological expedition of Nepal, Contribution No. 32, Seppyo, 39, 15-19, 1977.

Jacob, T., Wahr, J., Pfeffer, W., and Swenson, S.: Recent contributions of glaciers and ice caps to sea level rise, Nature, 482, 514-518, doi:10.1038/nature10847, 2012.
Jóhannesson, T., Raymond, C., and Waddington, E.: Time-scale for adjustment of glaciers to changes in mass balance, J. Glaciol., 35, 355-369, 1989.

Kääb, A.: Combination of SRTM3 and repeat ASTER data for deriving alpine glacier flow velocities in the Bhutan Himalaya, Remote Sens. Environ., 94, 463-474, 2005.

Kääb, A., Berthier, E., Nuth, C., Gardelle, J., and Arnaud, Y.: Contrasting patterns of early twenty-first-century glacier mass change in the Himalayas, Nature, 488, 495-498, doi:10.1038/nature11324, 2012.

Kripalani, R. H., Oh, J. H., Kulkarni, A., Sabade, S. S., and Chaudhari, H. S.: South Asian summer monsoon precipitation variability: Coupled climate model simulations and projections under IPCC AR4, Theor. Appl. Climatol., 90, 133-159, doi:10.1007/s00704-006-0282-0, 2007.

Lejeune, Y., Bertrand, J.-M., Wagnon, P., and Morin, S.: A physically based model of the year-round surface energy and mass balance of debris-covered glaciers, J. Glaciol., 59, 327-344, doi:10.3189/2013JoG12J149, 2013.

Liu, Y., Hou, S., Wang, Y., and Song, L.: Distribution of borehole temperature at four high-altitude alpine glaciers in central Asia, J. of Mountain Sci., 6, 221-227, 2009.

Lutz, A. F., Immerzeel, W. W., Gobiet, A., Pellicciotti, F., and Bierkens, M. F. P.: Comparison of climate change signals in CMIP3 and CMIP5 multi-model ensembles and implications for Central Asian glaciers, Hydrol. Earth Syst. Sci., 17, 3661-3677, doi:10.5194/hess-17-3661-2013, 2013.

Mae, S., Wushiki, H., Ageta, Y., and Higuchi, K.: Thermal drilling and temperature measurements in Khumbu Glacier, Nepal Himalayas, Seppyo, 37, 161-169, 1975.

Marzeion, B., Jarosch, A. H., and Hofer, M.: Past and future sealevel change from the surface mass balance of glaciers, The Cryosphere, 6, 1295-1322, doi:10.5194/tc-6-1295-2012, 2012.

Mathison, C., Wiltshire, A., Dimri, A., Falloon, P., Jacob, D., Kumar, P., Moors, E., Ridley, J., Siderius, C., Stoffel, M., and Yasunari, T.: Regional projections of North Indian climate for adaptation studies, Sci. Total Environ., 468, S4-S17, doi:10.1016/j.scitotenv.2012.04.066, 2013.

Mirza, M., Warrick, R., Ericksen, N., and Kenny, G.: Trends and persistence in precipitation in the Ganges, Brahmaputra and Meghna river basins, Hydrol. Sci. J., 43, 845-858, 1998.

Mölg, T., Chiang, J. C. H., Gohm, A., and Cullen, N. J.: Temporal precipitation variability versus altitude on a tropical high mountain: Observations and mesoscale atmospheric modelling, Q. J. Roy. Meteorol. Soc., 135, 1439-1455, doi:10.1002/qj.461, 2009.

Mölg, T., Maussion, F., Yang, W., and Scherer, D.: The footprint of Asian monsoon dynamics in the mass and energy balance of a Tibetan glacier, The Cryosphere, 6, 1445-1461, doi:10.5194/tc6-1445-2012, 2012.

Naito, N., Nakawo, M., Kadota, T., and Raymond, C. F.: Numerical simulation of recent shrinkage of Khumbu Glacier, Nepal Himalayas, in: Debris-covered Glaciers: Proceedings of an International Workshop Held at the University of Washington in Seattle, Washington, USA, 13-15 September 2000, Vol. 264, p. 245, International Association of Hydrological Sciences, 2000.

Nakawo, M., Yabuki, H., and Sakai, A.: Characteristics of Khumbu Glacier, Nepal Himalaya: recent change in the debris-covered area, Ann. Glaciol., 28, 118-122, 1999. 
Nepal, S., Krause, P., Flügel, W.-A., Fink, M., and Fischer, C.: Understanding the hydrological system dynamics of a glaciated alpine catchment in the Himalayan region using the J2000 hydrological model, Hydrol. Process., 28, 1329-1344, doi:10.1002/hyp.9627, 2013.

Nuimura, T., Fujita, K., Yamaguchi, S., and Sharma, R. R.: Elevation changes of glaciers revealed by multitemporal digital elevation models calibrated by GPS survey in the Khumbu region, Nepal Himalaya, 1992-2008, J. Glaciol., 58, 648-656, doi:10.3189/2012JoG11J061, 2012.

Oerlemans, J. and Fortuin, J. P. F.: Sensitivity of glaciers and small ice caps to greenhouse warming, Science, 258, 115-117, 1992.

Ohmura, A.: Enhanced temperature variability in high-altitude climate change, Theor. Appl. Climatol., 110, 499-508, doi:10.1007/s00704-012-0687-x, 2012.

Palazzi, E., Hardenberg, J., and Provenzale, A.: Precipitation in the Hindu-Kush Karakoram Himalaya: Observations and future scenarios, J. Geophys. Res.-Atmos., 118, 85-100, doi:10.1029/2012JD018697, 2013.

Pellicciotti, F., Buergi, C., Immerzeel, W., Konz, M., and Shrestha, A.: Challenges and uncertainties in hydrological modeling of remote Hindu Kush-Karakoram-Himalayan (HKH) basins: suggestions for calibration strategies, Mountain Res. Develop., 32, 3950, doi:10.1659/MRD-JOURNAL-D-11-00092.1, 2012.

Qi, W., Zhang, Y., Gao, J., Yang, X., Liu, L., and Khanal, N. R.: Climate change on the southern slope of Mt. Qomolangma (Everest) region in Nepal since 1971, J. Geogr. Sci., 23, 595-611, 2013.

Quincey, D. J., Luckman, A., and Benn, D.: Quantification of Everest region glacier velocities between 1992 and 2002, using satellite radar interferometry and feature tracking, J. Glaciol., 55, 596-606, doi:10.3189/002214309789470987, 2009.

Racoviteanu, A., Armstrong, R., and Williams, M.: Evaluation of an ice ablation model to estimate the contribution of melting glacier ice to annual discharge in the Nepalese Himalaya, Water Resour. Res., 49, 5117-5133, doi:10.1002/wrcr.20370, 2013.

Radić, V. and Hock, R.: Regional and global volumes of glaciers derived from statistical upscaling of glacier inventory data, J. Geophys. Res.-Earth Surf., 115, F01010, doi:10.1029/2009JF001373, 2010.

Radić, V., Bliss, A., Beedlow, A. C., Hock, R., Miles, E., and Cogley, J. G.: Regional and global projections of twenty-first century glacier mass changes in response to climate scenarios from global climate models, Clim. Dynam., 42, 37-58, doi:10.1007/s00382-013-1719-7, 2014.

Rangwala, I. and Miller, J.: Climate change in mountains: a review of elevation-dependent warming and its possible causes, Clim. Change, 114, 527-547, doi:10.1007/s10584-012-0419-3, 2012.

Rangwala, I., Miller, J. R., Russell, G. L., and Xu, M.: Using a global climate model to evaluate the influences of water vapor, snow cover and atmospheric aerosol on warming in the Tibetan Plateau during the twenty-first century, Clim. Dynam., 34, 859872, doi:10.1007/s00382-009-0564-1, 2009.

Rasmussen, L. A.: Meteorological controls on glacier mass balance in High Asia, An. Glaciol., 54, 352-359, doi:10.3189/2013AoG63A353, 2013.

Reid, T. D. and Brock, B. W.: An energy-balance model for debris-covered glaciers including heat conduction through the debris layer, J. Glaciol., 56, 903-916, doi:10.3189/002214310794457218, 2010.
Richardson, S. D. and Reynolds, J. M.: An overview of glacial hazards in the Himalayas, Quaternary Int., 65, 31-47, 2000.

Salerno, F., Buraschi, E., Bruccoleri, G., Tartari, G., and Smiraglia, C.: Glacier surface-area changes in Sagarmatha national park, Nepal, in the second half of the 20th century, by comparison of historical maps, J. Glaciol., 54, 738-752, doi:10.3189/002214308786570926, 2008.

Salerno, F., Guyennon, N., Thakuri, S., Viviano, G., Romano, E., Vuillermoz, E., Cristofanelli, P., Stocchi, P., Agrillo, G., Ma, Y., and Tartari, G.: Weak precipitation, warm winters and springs impact glaciers of south slopes of Mt. Everest (central Himalaya) in the last two decades (1994-2013), The Cryosphere Discuss., 8, 5911-5959, doi:10.5194/tcd-8-5911-2014, 2014.

Scherler, D., Bookhagen, B., and Strecker, M. R.: Spatially variable response of Himalayan glaciers to climate change affected by debris cover, Nat. Geosci., 4, 156-159, doi:10.1038/ngeo1068, 2011a.

Scherler, D., Bookhagen, B., and Strecker, M. R.: Hillslopeglacier coupling: The interplay of topography and glacial dynamics in High Asia, J. Geophys. Res.-Earth Surf., 116, F02019, doi:10.1029/2010JF001751, 2011b.

Shea, J., Wagnon, P., Immerzeel, W., Biron, R., Brun, F., and Pellicciotti, F.: A comparative high-altitude meteorological analysis from three catchments in the Nepalese Himalaya, Int. J. Water Resour. Manage., doi:10.1080/07900627.2015.1020417, 2015.

Shi, Y. and Liu, S.: Estimation on the response of glaciers in China to the global warming in the 21 st century, Chinese Sci. Bull., 45, 668-672, doi:10.1007/BF02886048, 2000.

Shrestha, A. B. and Aryal, R.: Climate change in Nepal and its impact on Himalayan glaciers, Reg. Environ. Change, 11, 65-77, doi:10.1007/s10113-010-0174-9, 2011.

Shrestha, A. B., Wake, C. P., Mayewski, P. A., and Dibb, J. E.: Maximum temperature trends in the Himalaya and its vicinity: an analysis based on temperature records from Nepal for the period 1971-94, J. Climate, 12, 2775-2786, doi:10.1175/15200442(1999)012<2775:MTTITH>2.0.CO;2, 1999.

Singh, P., Kumar, N., Ramasastri, K., and Singh, Y.: Influence of a fine debris layer on the melting of snow and ice on a Himalayan Glacier, in: Debris Covered Glaciers, Vol. 264 of IAHS Proceedings, 63-69, IAHS, 2000.

Stahl, K., Moore, R. D., Shea, J. M., Hutchinson, D., and Cannon, A. J.: Coupled modelling of glacier and streamflow response to future climate scenarios, Water Resour. Res., 440, W02422, doi:10.1029/2007WR005956, 2008.

Thakuri, S., Salerno, F., Smiraglia, C., Bolch, T., D’Agata, C., Viviano, G., and Tartari, G.: Tracing glacier changes since the 1960s on the south slope of Mt. Everest (central Southern Himalaya) using optical satellite imagery, The Cryosphere, 8 , 1297-1315, doi:10.5194/tc-8-1297-2014, 2014.

Thompson, S. S., Benn, D. I., Dennis, K., and Luckman, A.: A rapidly growing moraine-dammed glacial lake on Ngozumpa Glacier, Nepal, Geomorphology, 145, 1-11, doi:10.1016/j.geomorph.2011.08.015, 2012.

Viviroli, D., Dürr, H. H., Messerli, B., Meybeck, M., and Weingartner, R.: Mountains of the world, water towers for humanity: Typology, mapping, and global significance, Water Resour. Res., 43, W07447, doi:10.1029/2006WR005653, 2007.

Wagnon, P., Vincent, C., Arnaud, Y., Berthier, E., Vuillermoz, E., Gruber, S., Ménégoz, M., Gilbert, A., Dumont, M., Shea, J. 
M., Stumm, D., and Pokhrel, B. K.: Seasonal and annual mass balances of Mera and Pokalde glaciers (Nepal Himalaya) since 2007, The Cryosphere, 7, 1769-1786, doi:10.5194/tc-7-17692013, 2013.

Weertman, J.: On the sliding of glaciers, J. Glaciol., 3, 33-38, 1957. Williams, V. S.: Present and former equilibrium-line altitudes near Mount Everest, Nepal and Tibet, Arctic Alpine Res., 15, 201211, 1983.

Yao, T., Thompson, L., Yang, W., Yu, W., Gao, Y., Guo, X., Yang, X., Duan, K., Zhao, H., Xu, B.and Pu, J., Lu, A., Xiang, Y., Kattel, D., and Joswiak, D.: Different glacier status with atmospheric circulations in Tibetan Plateau and surroundings, Nat. Clim. Change, 2, 663-667, doi:10.1038/NCLIMATE1580, 2012.
Yatagai, A., Arakawa, O., Kamiguchi, K., Kawamoto, H., Nodzu, M. I., and Hamada, A.: A 44-year daily gridded precipitation dataset for Asia based on a dense network of rain gauges, Sola, 5, 137-140, doi:10.2151/sola.2009-035, 2009.

Yatagai, A., Kamiguchi, K., Arakawa, O., Hamada, A., Yasutomi, N., and Kitoh, A.: APHRODITE: Constructing a Long-Term Daily Gridded Precipitation Dataset for Asia Based on a Dense Network of Rain Gauges, B. Am. Meteorol. Soc., 93, 1401-1415, doi:10.1175/BAMS-D-11-00122.1, 2012.

Zhang, T., Xiao, C., Colgan, W., Qin, X., Du, W., Sun, W., Liu, Y., and Ding, M.: Observed and modelled ice temperature and velocity along the main flowline of East Rongbuk Glacier, Qomolangma (Mount Everest), Himalaya, J. Glaciol., 59, 438-448, doi:10.3189/2013JoG12J202, 2013. 